\title{
EFEITO DO ÁCIDO LINOLÉICO CONJUGADO trans-10, cis-12 NA REGULAÇÃO DA LIPOGÊNESE E EXPRESSÃO GÊNICA EM CULTURAS DE TECIDO ADIPOSO DE SUÍNOS EM CRESCIMENTO
}

\author{
ANDREA A. F. BRASIL VIEIRA JosÉ
}

Tese apresentada à Escola Superior de Agricultura "Luiz de Queiroz", Universidade de São Paulo, para obtenção do título de Doutor em Agronomia, Área de Concentração: Ciência Animal e Pastagens.

P I R A C I C A B A

Estado de São Paulo - Brasil

Fevereiro - 2005 


\title{
EFEITO DO ÁCIDO LINOLÉICO CONJUGADO trans-10, cis-12 NA REGULAÇÃO DA LIPOGÊNESE E EXPRESSÃO GÊNICA EM CULTURAS DE TECIDO ADIPOSO DE SUÍNOS EM CRESCIMENTO
}

\author{
ANDREA A. F. BRASIL VIEIRA JosÉ \\ Engenheiro Agrônomo
}

Orientador: Prof. Dr. DANTE P. DUARTE LANNA

\begin{abstract}
Tese apresentada à Escola Superior de Agricultura "Luiz de Queiroz", Universidade de São Paulo, para obtenção do título de Doutor em Agronomia, Área de Concentração: Ciência Animal e Pastagens.
\end{abstract}

\author{
P I R A C I C A B A \\ Estado de São Paulo - Brasil
}

Fevereiro - 2005 
Dados Internacionais de Catalogação na Publicação (CIP) DIVISÃO DE BIBLIOTECA E DOCUMENTAÇÃO - ESALQ/USP

José, Andrea Alessandra Filomena Brasil Vieira

Efeito ao ácido linoléico conjugado trans-10, cis-12 na regulação da lipogênese e expressão gênica em culturas de tecido adiposo de suínos em crescimento / Andrea Alessandra Filomena Brasil Vieira José. - - Piracicaba, 2005.

60 p. : il.

Tese (Doutorado) - - Escola Superior de Agricultura Luiz de Queiroz, 2005.

Bibliografia.

1. Ácido graxos 2. Cultura de tecido animal 3. Expressão gênica 4. Metabolismo animal 5. Suíno 6. Tecido adiposo I. Título

CDD 636.4

"Permitida a cópia total ou parcial deste documento, desde que citada a fonte - $\mathrm{O}$ autor" 
“FELIZ DE QUEM OLHA PELAS JANELAS DA SABEDORIA E AUSCULTA À SUA PORTA; QUEM REPOUSA JUNTO À SUA CASA E, FIXANDO A ESTACA ÀS SUAS PAREDES, INSTALA A CABANA AO SEU LADO E REPOUSA NA MORADIA DA FELICIDADE PARA SEMPRE” (Eclo 14, 24-25)

\section{DEDICO}

Aos meus pais, Conceição e Jamil, a minha tia Clélia, minha sobrinha Carolina, meus irmãos Alexandre e Júnior e minha cunhada Sílvia. Pela compreensão, força e carinho que sempre me deram em todos os momentos da minha caminhada e, principalmente, pela paciência em vários momentos desta fase...Obrigada. 
Meus agradecimentos,

A Deus por tudo e Nossa Senhora pelo colo de mãe.

Ao Prof. Dante por mais um período de orientação, ensinamentos, incentivos e um ambiente de respeito, igualdade, amizade e companheirismo.

A FAPESP pela bolsa de estudos e subsídios para o desenvolvimento deste projeto.

A ESALQ, por todo suporte e aos seus funcionários e docentes que estiveram juntos nesta fase.

A todos os funcionários do Departamento de Zootecnia.

Aos Drs. Dale Bauman e Lance Baumgard, por terem cedido o CLA para realização do experimento.

A minha amada Carolina pelas noites de companhia no laboratório e por fazer da minha vida uma constante alegria.

A Profa. Conceição W. B. V. José, minha amada mãe, por toda correção da tese.

Ao Prof. Irineu Umberto Packer pela super ajuda, disponibilidade e ensinamentos estatísticos.

A todos os companheiros e ótimos profissionais do Laboratório de Nutrição e Crescimento Animal - Marco Antônio, Liana, Rodrigo de Almeida, Dimas, Amanda, Alexandre, Beatriz, Giovana, Amoracyr, Juliano, Eduardo Eifert, Rodrigo Goulart, Laudi, Adriana, Ana Paula, Maria Antônia, Ana Júlia, Nice e Vilma pelo apoio, amizade e por tornar esta fase tão suave e um ambiente de trabalho repleto de respeito, companheirismo e risadas (nas horas vagas!!!). Cada um, com seu jeito especial de ser.

Ao Marco Antônio da Gama e a Liana Calegare, pelos ensinamentos, companheirismo e ajuda nas coletas.

Ao Rodrigo de Almeida, por toda ajuda, calma e discernimento nos momentos difíceis. 
A minha querida amiga, ótima estagiária e profissional Aline Urban.

A Dra. Lúcia Alvarez pela amizade e por ter me ensinado toda a arte laboratorial.

Aos Professores José Eurico Cyrino - Zico, Flávio Meirelles, José Fernando Menten, Marília Oetterer, Antônio Figueira, Marisa d’Arce, Virgílio Nascimento, Luiz Coutinho, Márcio de Castro, Francisco Monteiro, Albino Luchiari e Eduardo Delgado, por toda ajuda pessoal e/ou profissional.

Aos superprofissionais Helena Alves, Vagner Benedito, Aline Raccanice, Aelson Brum, Giovana Krempel, Raul Almeida e Othon Abrahão, pela ajuda nas diferentes fases desta tese.

Aos Laboratórios de Biotecnologia Animal (ESALQ), de Biologia Molecular de Plantas (ESALQ), de Morfofisiologia Molecular e Desenvolvimento (FZEA), de Melhoramento de Plantas (CENA) e de Experimentação Nuclear (CENA) por toda ajuda e desprendimento.

Ao Seu Pires, Dona Maria, Seu Dito, Adão e Sokdô, pela super ajuda com os animais e por fazer da simplicidade da vida sua essência mais profunda.

Aos meus compadres Carlos e Nirlei - Bruno Giaveno por um "presente” tão abençoado, amado e especial: o Thomaz.

Aos meus queridos amigos que mesmo não participando diretamente, estiveram comigo em todos os momentos da minha caminhada.

Ao meu querido Fred ...cão amigo e companheiro em todos os momentos. 


\section{SUMÁRIO}

Página

LISTA DE FIGURAS............................................................................. vii

LISTA DE TABELAS................................................................................. ix

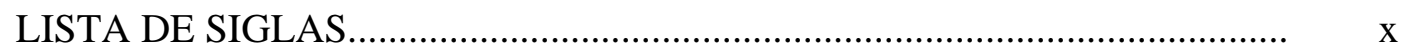

RESUMO........................................................................................ $\mathrm{xi}$

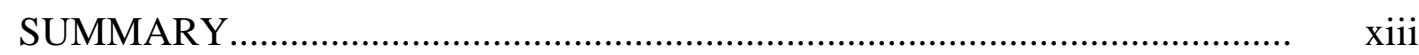

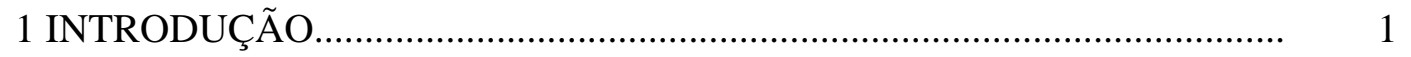

2 REVISÃO DE LITERATURA.................................................................. 3

2.1 Descoberta dos ácidos graxos conjugados................................................... 3

$2.2 \mathrm{O}$ ácido linoléico conjugado ...................................................................... 4

2.3 Efeitos fisiológicos dos isômeros de CLA..................................................... 5

2.4 Efeitos do CLA na saúde humana................................................................. 6

2.5 CLA para animais em crescimento e lactação................................................. 8

2.6 Regulação da expressão gênica....................................................................... 12

3 VALIDAÇÃO DO USO DE PVA COMO CARREADOR DE ÁCIDOS GRAXOS EM CULTURA DE EXPLANTES DE TECIDO ADIPOSO ........................................................................................ 16

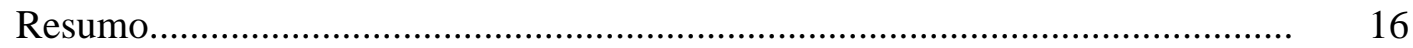

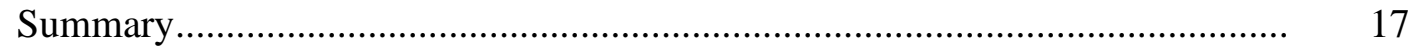

3.1 Introdução.............................................................................................. 18

3.2 Material e Métodos........................................................................................ 19

3.2.1 Culturas de explantes de tecido adiposo de suínos................................... 19

3.2.2 Ensaio de Lipogênese.................................................................................. $\quad 20$ 
3.2.3 Ensaio de lipólise............................................................................. 21

3.2.4 Análise estatística.................................................................................. 21

3.3 Resultados e Discussão......................................................................... 22

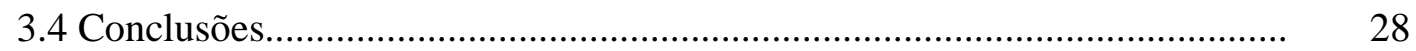

4 EFEITO DO ÁCIDO LINOLÉICO CONJUGADO EM CULTURAS DE EXPLANTE DE TECIDO ADIPOSO DE SUÍNOS EM CRESCIMENTO ................................................................................. 30

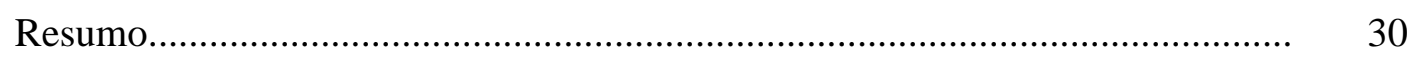

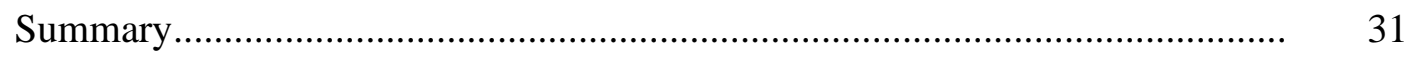

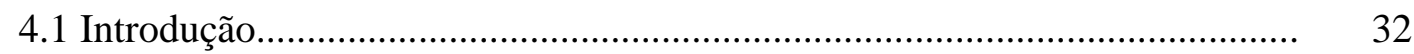

4.2 Material e Métodos........................................................................................ 34

4.2.1 Culturas de explantes de tecido adiposo de suínos...................................... 34

4.2.2 Formação do complexo ácido graxo - poliivinil álcool............................... 35

4.2.3 Ensaio de Lipogênese................................................................................ 35

4.2.4 Quantificação do RNA mensageiro da sintase de ácido graxo................... 36

4.2.4.1 Extração de RNA total e síntese de DNAc............................................... 36

4.2.4.2 PCR em Tempo Real........................................................................... 36

4.2.5 Ensaio de lipólise................................................................................ 37

4.2.6 Ensaios enzimáticos................................................................................ 38

4.2.6.1 Homogeneização dos explantes de tecido adiposo................................. 38

4.2.6.2 Teor de proteína.................................................................................... 38

4.2.6.3 Sintase de ácido graxo (EC 2.3.1.85)...................................................... 38

4.2.6.4 NADP-malato desidrogenase (EC 1.1.1.40)............................................ 39

4.2.6.5 Atividade da 6-fosfogluconato desidrogenase (EC 1.1.1.44) e glucose 6fosfato desidrogenase (EC 1.1.1.49)...................................................... 39

4.2.7 Análise estatística................................................................................... 39

4.3 Resultados e Discussão................................................................................ 40

4.5 Conclusões.................................................................................................. 47

5 CONCLUSÕES GERAIS..................................................................... 48

REFERÊNCIAS BIBLIOGRÁFICAS........................................................... 49 


\section{LISTA DE FIGURAS}

Página

1 Lipogênese em explantes de tecido adiposo após 24 h de cultura com I+D (insulina e dexametasona) ou $200 \mu \mathrm{M}$ BSA (insulina, dexametasona e albumina sérica bovina). Resultados expressos em $\mu$ moles de ${ }^{14} \mathrm{C}$-glucose incorporada por g de tecido após 2 h de incubação sem adições (Basal) ou com $1000 \mathrm{ng} / \mathrm{mL}$ de insulina (INS) 


\section{LISTA DE TABELAS}

Página

1. Taxas de lipogênese em explantes de tecido adiposo, após 4, 12, 24 e 48 horas de cultura com diferentes tratamentos.

2 Taxas de lipólise (liberação de ácidos graxos em 2 h de incubação) em explantes de tecido adiposo mantidos em cultura por 48 horas sob diferentes tratamentos.

3 Análise de perfil de ácidos graxos do ácido linoléico conjugado utilizado..

4 Taxas de lipogênese em explantes de tecido adiposo, após 4, 12, 24 e 48 horas de cultura com diferentes tratamentos.

5 Atividades enzimáticas de explante de tecido adiposo, após 48 h de cultura.

6 Valores de transcritos do RNA mensageiro da FAS.

7 Taxas de lipólise em explantes de tecido adiposo mantidos em cultura por 48 horas sob diferentes tratamentos. 


\section{LISTA DE SIGLAS}

6-PGDH: 6-fosfogluconato desidrogenase

AG: ácido graxo

AGNE: ácido graxo não esterificado

BSA: albumina sérica bovina

CLA: ácido linoléico conjugado

FAS: sintase de ácido graxo

G-6PDH: glucose 6- fosfato desidrogenase

LA: ácido linoléico

NADP-MD: NADP-malato desidrogenase

PCR: reação em cadeia da polimerase

pGH: hormônio do crescimento recombinante suíno

PUFA: ácidos graxos poliinsaturados

PVA: poliivinil álcool

RT: transcrição reversa

SCD: estearoil conezima A dessaturase 


\title{
EFEITO DO ÁCIDO LINOLÉICO CONJUGADO trans-10, cis-12 NA REGULAÇÃO DA LIPOGÊNESE E EXPRESSÃO GÊNICA EM CULTURAS DE TECIDO ADIPOSO DE SUÍNOS EM CRESCIMENTO
}

\author{
Autora: ANDREA A. F. BRASIL VIEIRA JOSÉ \\ Orientador: Prof. Dr. DANTE P. D. LANNA
}

RESUMO

O objetivo deste estudo foi avaliar os efeitos do ácido linoléico conjugado (CLA), especificamente do isômero trans-10, cis-12 em culturas de explante de tecido adiposo de suínos, em crescimento. Respostas foram avaliadas para a lipogênese, lipólise, abundância do RNA mensageiro da enzima sintase de ácido graxo (FAS) e atividade de enzimas lipogênicas. Como a adição de CLA ao meio de cultura necessita de uma molécula carreadora, um ensaio preliminar teve como objetivo testar o uso da albumina sérica bovina (BSA) e validar a sua substituição por poliivinil álcool (PVA), avaliando seu efeito no sistema de cultura. Explantes de tecido adiposo de nove suínos, em crescimento, $(78 \pm 3 \mathrm{~kg}$ ) foram submetidos à cultura em meio 199 (com adição de 100 $\mathrm{ng} / \mathrm{mL}$ de insulina, $10 \mathrm{nM}$ de dexametasona e antibióticos) por 4, 12, 24 e 48 horas, com os tratamentos: Controle - meio 199; PVA - meio 199 com $100 \mu \mathrm{M}$ de PVA e pGH meio 199 com $100 \mathrm{ng} / \mathrm{mL}$ de pGH (hormônio do crescimento suíno) e $100 \mu \mathrm{M}$ de PVA. Após cada período de cultura, explantes foram coletados para determinação da 
lipogênese pela incorporação de glucose $-{ }^{14} \mathrm{C}$ por $2 \mathrm{~h}$ com e sem adição de insulina. Após $48 \mathrm{~h}$, a taxa de lipólise foi avaliada pela liberação de ácidos graxos não esterificados (AGNE) por 2 horas com e sem isoproterenol. Nos ensaios preliminares, foram utilizadas diferentes fontes comerciais e lotes de BSA, que provocaram alterações nas taxas lipogênicas, provavelmente pela presença de outras substâncias contaminantes Diferentemente da BSA, o PVA não teve efeito sobre a síntese de lipídios como na resposta à insulina. No meio com PVA, o controle positivo (pGH) diminuiu a incorporação de glucose em lipídios $(\mathrm{P}<0,01)$ mantendo a resposta da insulina $(\mathrm{P}<0,05)$. Para a lipólise, também, não houve diferença entre Controle e PVA e o controle positivo (pGH) aumentou a lipólise basal e estimulada por isoproterenol $(\mathrm{P}<0,05)$, conforme o esperado. O PVA, ao contrário da BSA, se mostrou um carreador para o tratamento que não apresenta efeitos sobre os parâmetros de lipogênese e lipólise. Desta forma, no estudo do CLA, o PVA foi utilizado ao invés da BSA, no meio de cultura. Os tratamentos foram: Controle - meio 199 com $100 \mu \mathrm{M}$ de PVA; CLA200 - $200 \mu \mathrm{M}$ de CLA trans-10, cis-12; CLA50 - $50 \mu \mathrm{M}$ de CLA trans-10, cis-12; LA - $200 \mu \mathrm{M}$ de ácido de linoléico e pGH - $100 \mathrm{ng} / \mathrm{mL}$ de pGH e $100 \mu \mathrm{M}$ de PVA. Os ácidos graxos foram complexados ao PVA (2:1). Após 4, 12, 24 e 48 h de cultura, nos meios acima, os explantes foram coletados e submetidos ao ensaio de lipogênese. Após $24 \mathrm{~h}$ de cultura, o RNAm da FAS foi quantificado por RT-PCR em Tempo Real. A lipólise e atividade das enzimas FAS, glucose 6-fosfato desidrogenase, 6-fosfogluconato desidrogenase e NADP-malato desidrogenase, foram avaliadas após 48 horas. A incorporação de glucose basal e estimulada diminuiu $(P<0,05)$ e a lipólise basal e estimulada aumentou $(P<0,05)$ com o tratamento com pGH, conforme esperado. $\mathrm{O}$ ácido linoléico não alterou nenhum dos parâmetros avaliados. O CLA na dose maior $(200 \mu \mathrm{M})$ reduziu a atividade da FAS $(P<0,05)$, mas a redução observada na lipogênese não foi significativa. Coerente, com as reduções na atividade da FAS e na lipogênese, os níveis de RNAm da FAS diminuíram com o tratamento com CLA na dose mais elevada. Enzimas da síntese de NADPH não foram afetadas pelos tratamentos. O tratamento com CLA, nas duas doses, não causou efeito na taxa de liberação de AGNE após $48 \mathrm{~h}$ de cultura. Estes dados sugerem que CLA trans-10, cis-12 tem efeito sobre o sistema envolvido na lipogênese, mas não sobre a lipólise. 


\title{
EFFECT OF trans-10, cis-12 CONJUGATED LINOLEIC ACID ON LIPOGENESIS AND GENE EXPRESSION REGULATION IN ADIPOSE TISSUE CULTURES FROM GROWING PIGS
}

\author{
Author. ANDREA A. F. BRASIL VIEIRA JOSÉ \\ Adviser: Prof. Dr. DANTE P. D. LANNA
}

SUMMARY

The objective of this study was to evaluate the effects of conjugated linoleic acid (CLA), specifically the trans-10, cis-12 isomer on cultures of adipose tissue explants from growing pigs. Responses evaluated included lipogenesis, lipolysis, fatty acid synthase (FAS) messenger RNA (mRNA) abundance and activities of enzymes in the lipogenic pathway. As addition of CLA in culture medium requires a carrier molecule, a preliminary assay evaluated thē use of bovine serum albumin (BSA) and polyvinyl alcohol (PVA) to deliver fatty acids to the medium. Adipose tissue explants from nine growing pigs $(78 \pm 3 \mathrm{~kg}$ ) were cultured in medium 199 (with addition of $100 \mathrm{ng} / \mathrm{mL}$ of insulin, $10 \mathrm{nM}$ of dexamethasone and antibiotics) for 4, 12, 24 and 48 hours. Treatments were Control - medium 199; PVA - medium 199 with $100 \mu \mathrm{M}$ of PVA and pGH medium 199 with $100 \mathrm{ng} / \mathrm{mL}$ of pGH (swine growth hormone) and $100 \mu \mathrm{M}$ of PVA. After each culture period, explants were collected and assayed for lipogenesis (rates of ${ }^{14} \mathrm{C}$ labeled glucose incorporation over a subsequent $2 \mathrm{~h}$ incubation with or without 
insulin). After $48 \mathrm{~h}$, lipolysys was analyzed for release of non-esterified fatty acid (NEFA) over a subsequent $2 \mathrm{~h}$ with or without isoproterenol. Preliminary results showed that different commercial sources and lots of BSA altered the rates of lipogenesis, due to presence of contaminants. Conversely to BSA, PVA had no effect on the rates of lipid synthesis, and did not alter the expected responses to the positive control ( $\mathrm{pGH}$ ), which reduced glucose incorporation in lipids $(\mathrm{P}<0,05)$ as expected. Similar results were found for lipolysis, with no difference between Control and PVA. The pGH treatment increased $(\mathrm{P}<0.05)$ both basal and stimulated lipolysys in the presence of PVA. Unlikely BSA, PVA did not alter rates of lipogenesis or responses to insulin and could be used in further culture studies. Thus, for the CLA studies, the PVA was used in exchange for BSA in the culture medium. Treatments were Control - medium 199 with $100 \mu \mathrm{M}$ of PVA; CLA200 - $200 \mu \mathrm{M}$ of trans-10, cis-12 CLA; CLA50 - $50 \mu \mathrm{M}$ of trans-10, cis-12 CLA; LA - $200 \mu \mathrm{M}$ of linoleic acid; and pGH $-100 \mathrm{ng} / \mathrm{mL}$ of pGH and $100 \mu \mathrm{M}$ of PVA. The fatty acids were complexed with PVA (2:1). Aftet 4, 12, 24 and $48 \mathrm{~h}$ in medium described above, explants were collected and assayed for lipogenesis. After $24 \mathrm{~h}$, the FAS mRNA were quantified by Real Time RT-PCR. Lipolysis and enzymes activities for FAS, glucose 6-phosphate dehydrogenase, 6-phosphogluconate dehydrogenase and NADP-malate dehydrogenase were evaluated after $48 \mathrm{~h}$ of culture. Basal and insulinstimulated glucose incorporation were significantly decreased $(\mathrm{P}<0.05)$ and basal and isoproterenol-stimulated lipolysis were increased $(\mathrm{P}<0.05)$ by the positive control $\mathrm{pGH}$. Linoleic acid had no effect on any parameter evaluated. CLA treatment at the highest dose $(200 \mu \mathrm{M})$ decreased FAS activity $(P<0.05)$, but the lypogenesis reduction observed did not achieve significancy. The CLA treatment did also decrease FAS mRNA levels. The NADPH generating enzymes were not affected by any treatment. CLA treatment on any dose had no effect $(\mathrm{P}>0.05)$ on NEFA release after $48 \mathrm{~h}$ of culture. These data suggest trans-10, cis-12 CLA has an inhibitory effect on lipogenesis, but no effect on lipid mobilization was observed. 


\section{INTRODUÇÃO}

Aumentar a eficiência da produção animal, requer o conhecimento dos processos biológicos envolvidos no metabolismo de nutrientes. Outros objetivos práticos da pesquisa, na área de metabolismo animal, envolvem o desenvolvimento de soluções para doenças metabólicas muito prevalentes na população humana e nos animais utilizados para produção de alimentos.

Diversos nutrientes, hormônios e modificadores metabólicos, com importantes efeitos sobre o metabolismo de lipídios, têm sido estudados. Recentemente, um objetivo importante da pesquisa em nutrição tem sido a avaliação dos efeitos de lipídios bioativos. Ou seja, lipídios capazes de ter efeitos além daqueles esperados pela sua contribuição nutricional/energética.

Um componente alimentar funcional bastante estudado, nas últimas décadas, é o ácido linoléico conjugado (CLA). Certos isômeros pertencentes a este grupo molecular têm sido relacionados à redução da carcinogênese (Pariza et al., 1979), efeito antiobesidade, à alteração da composição corporal de camundongos e suínos (Bee, 2000; Dugan et al., 1997; Dugan et al., 1999; Ostrowska et al., 1999; Park et al., 1997; ThielCooper et al., 2001), à alteração da composição do leite de vacas (Baumgard et al., 2000; Chouinard et al., 1999; Giesy et al., 1999; Medeiros et al., 2000) e aos efeitos positivos sobre doenças como diabetes mellitus, agregação de plaquetas e funcionamento do sistema imunológico (Sebedio et al., 1999).

Estão particularmente bem definidos os efeitos de um isômero do CLA, o trans10, cis-12, na redução da síntese de gordura na glândula mamária. Este isômero reduz os níveis de RNA mensageiro (RNAm) de enzimas lipogênicas (Baumgard et al., 2002; Peterson et al., 2003), reduz a atividade da enzima lipoproteína lipase em culturas de 
adipócitos de camundongos 3T3-L1 (Park et al., 1999), inibe a atividade da estearoil coenzima A dessaturase (SCD) (Baumgard et al., 2001; Park et al., 2000) e reduz a abundância de RNAm da SCD (Choi et al., 2000; Lee et al., 1998), tem efeitos antiadipogênicos em humanos (Brown \& McIntosh, 2003) e altera a razão LDL:HDL em humanos saudáveis (Tricon et al., 2004).

A partir destas constatações, o objetivo deste trabalho foi observar o efeito do CLA trans-10, cis-12 no metabolismo lipídico, em culturas de explante de tecido adiposo subcutâneo de suínos em crescimento. Culturas de explante permitem a condução de um grande número de avaliações, e sendo uma cultura primária, apresenta uma condição geralmente próxima à do tecido animal in vivo. Entretanto, no sistema in vitro, há a necessidade de utilizar uma molécula carreadora do CLA trans-10, cis-12 no meio de cultura. Assim, o primeiro objetivo deste trabalho foi validar a utilização do poliivinil álcool (PVA), como macromolécula carreadora de ácido graxo que não altere o metabolismo das células em cultura, isto é, inerte no sistema de cultura. Posteriormente, foram testados os efeitos do CLA sobre a lipogênese, a lipólise, a atividade das enzimas lipogênicas e a expressão da sintase de ácidos graxos. 


\section{REVISÃO DE LITERATURA}

\subsection{Descoberta dos ácidos linoléicos conjugados}

A presença de ácidos graxos com duplas ligações conjugadas foi primeiramente estabelecida por Booth et al. (1935), que observaram apreciável aumento na absorção de luz ultravioleta a $230 \mathrm{~nm}$ em amostras de gordura do leite, obtidas de vacas retiradas do pastejo após o inverno. Corroborando, Dan et al. (1935) administraram óleo à dieta de vacas e verificaram, na manteiga do leite destas vacas, ácido graxo (AG) com alto coeficiente de extinção, diferentemente dos originalmente presentes no óleo. Em trabalho anterior, Dan \& Moore (1933) concluíram que esse aumento na absorção de AG poderia estar relacionado com a mudança isomérica nas ligações insaturadas destes ácidos graxos.

Reiser (1951) foi o primeiro pesquisador a reportar a biohidrogenação de AG de cadeia longa no rúmen. Posteriormente, outros experimentos foram desenvolvidos observando esse processo, bem como os produtos originados. Assim, Smith et al. (1954) observaram, em espectro infravermelho, que na concentração de ácidos graxos poliinsaturados (PUFA), obtidos da gordura do leite, havia alta quantidade de ácido dienóico conjugado cis, trans (trans, cis) com possibilidade de alguns serem trans, trans. Estes dados foram confirmados posteriormente por Scott et al. (1959).

Na década seguinte, Kepler et al. (1966), em um ensaio de biohidrogenação in vitro com Butyrivibrio fibrisolvens e ácidos graxos marcados com ${ }^{14} \mathrm{C}$, como o ácido linoléico (LA), observaram que o primeiro intermediário produzido era o isômero octadecadienóico conjugado cis, trans (ou trans, cis ou ambos).

Parodi (1977), utilizando amostras de gordura do leite obtidas de manteiga, concluiu que o ácido graxo desta gordura do leite, o ácido octadecadienóico conjugado cis, trans, (trans, cis), era essencialmente o ácido linoléico conjugado cis-9, trans-11. Dois anos depois Pariza et al. (1979) observaram que, na carne bovina grelhada, havia um componente que causava alteração nas células cancerígenas, e tentaram identificar este componente. Pariza et al. (1983) notaram que extratos da carne grelhada possuíam 
tanto componentes mutagênicos como antimutagênicos, e que estavam presentes independentemente da cocção.

Já na década de 80, Ha et al. (1987) isolaram de extratos de carne bovina grelhada, um componente anticarcinogênico, e estabeleceram que constituía uma série de isômeros dienóicos conjugados do ácido linoléico. Posteriormente, Chin et al. (1992) observaram que o cis-9, trans-11 foi o isômero mais encontrado em queijos e gorduras da carne enquanto outros isômeros representavam frações menores. A partir destes achados, muitas pesquisas surgiram com o intuito de esclarecer os mecanismos de produção e ação deste ácido linoléico conjugado e, principalmente, de cada isômero que o compõe.

\subsection{O ácido linoléico conjugado}

Com o desenvolvimento de pesquisas relacionadas, o processo de formação e atuação deste ácido linoléico conjugado foi sendo esclarecido e, em 1987, o termo ácido linoléico conjugado se tornou referido e conhecido como CLA. Este termo, embora comumente utilizado no singular, denomina um conjunto de isômeros posicionais e geométricos do ácido octadecadienóico com duplas ligações conjugadas (i.e. duas duplas ligações separadas por uma ligação simples), que podem ser encontradas nas posições dos carbonos 9 e 11, 10 e 12 ou 11 e 13, entre outras e podem ser em ambas configurações, cis e trans. Estudos posteriores demonstraram que a posição da dupla ligação e o seu tipo de isomeria geométrica determinam o papel do CLA no metabolismo. Embora possam haver diversos isômeros possíveis, dois deles (CLA trans10, cis-12 e CLA cis-9, trans-11) têm mostrado pronunciados e, muitas vezes, distintos efeitos biológicos (Pariza et al., 2001).

Segundo Bauman et al. (1999), o CLA cis-9, trans-11 encontrado na gordura do leite e da carne de ruminantes é oriundo de duas fontes. Em uma, é formado como um intermediário na via pela qual o ácido linoléico é biohidrogenado a ácido esteárico e este processo ocorre pela ação de microorganismos presentes no rúmen. Na segunda, é sintetizado nos tecidos animais a partir do ácido graxo trans-11 $\mathrm{C}_{18: 1}$ pela ação da enzima estearoil coenzima A dessaturase ( $\Delta^{9}$ dessaturase ou SCD). Griinari et al. (1998) 
demonstraram que uma alteração no ambiente ruminal induzida por dietas com alto concentrado, é associada a uma mudança no perfil de ácido octadecenóico trans na gordura do leite. Nesta situação, o ácido graxo trans-11 octadecenóico é substituído pelo trans-10 $\mathrm{C}_{18: 1}$ como o isômero trans $\mathrm{C}_{18: 1}$, predominante na gordura do leite. Uma suposta via para produção ruminal do trans-10 octadecenóico tem sido proposta e envolve a enzima isomerase cis-9, trans-10 específica, em bactérias ruminais, com a formação de uma estrutura com dupla ligação conjugada trans-10, cis-12, como um primeiro intermediário. Evidências posteriores suportaram que essa bactéria é favorecida por dietas com baixa fibra, o que gera um aumento na proporção do isômero trans-10, cis-12, na gordura do leite (Piperova et al., 2000).

Corl et al. (2001), em avaliações da síntese endógena de cis-9, trans-11 em vacas lactantes, com diferentes tratamentos, contendo óleo vegetal parcialmente hidrogenado como fonte de trans-11 $\mathrm{C}_{18: 1}$ e ácido estercúlico como fonte de ácido graxo ciclopropeno (i.e. inibidor específico da SCD), concluíram que a síntese endógena é a principal fonte de cis-9, trans-11 na gordura do leite de vacas lactantes. Conclusivamente, a concentração dos isômeros cis-9, trans-11 e trans-10, cis-12 em produtos lácteos varia em função da dieta fornecida aos animais.

\subsection{Efeitos fisiológicos dos isômeros de CLA}

Park et al. (1999) indicaram que mudanças na composição corporal de camundongos são resultantes, especificamente, da atuação do isômero trans-10, cis-12. Neste experimento, os animais receberam um preparado enriquecido com cis-9, trans-11 ou trans-10, cis-12, e mudanças na composição corporal como redução na gordura, elevação na água, proteína e cinzas foram associadas ao CLA trans-10, cis-12. Neste mesmo experimento, em culturas de adipócitos de camundongos 3T3-L1, o isômero trans-10, cis-12 reduziu a atividade da enzima lipoproteína lipase (LPL) e as concentrações de triacilgliceróis e glicerol e elevou a liberação de glicerol no meio. Em contraste, os isômeros cis-9, trans-11 e trans-9, trans-11 não afetaram estes parâmetros.

Corroborando estas constatações, o CLA trans-10, cis-12 inibiu a atividade da SCD (Park et al., 2000) e a abundância do RNA mensageiro (RNAm) (Lee et al., 1998) 
enquanto o cis-9, trans-11 e o trans-9, trans-11 não afetaram tais medidas. Park et al. (2000) observaram que outros ácidos graxos como o trans-10 octadecenoato não foi inibitório, enquanto o cis-12 octadecenato causou uma inibição, mas não tão intensa quanto à ocasionada pelo trans-10, cis-12. Estes pesquisadores concluíram que a dupla ligação na configuração cis-12 parece ser a estrutura chave característica na inibição da atividade da SCD, especialmente quando acoplada a uma ligação trans-10, enquanto a cis-11 é menos efetiva.

Baumgard et al. (2000) observaram que a infusão abomasal do CLA trans-10, cis12 reduziu a produção e porcentagem de gordura do leite. Os tratamentos tiveram um efeito mínimo na concentração de glucose plasmática, ácidos graxos não esterificados, insulina e fator de crescimento semelhante à insulina-I (IGF-I). A partir destas conclusões, a multifuncionalidade aparente do CLA tem sido mais intrigante e menos confusa. Diferentes isômeros parecem produzir diferentes efeitos. É também praticamente certo que mais de um mecanismo bioquímico está envolvido em vários efeitos fisiológicos do CLA (Pariza et al., 2000).

\subsection{Efeitos do CLA na saúde humana}

Muitos efeitos têm sido atribuídos ao CLA em relação à saúde humana e, sua atividade biológica foi descoberta devido ao efeito inibitório na carcinogênese epidermal, induzida quimicamente em camundongos (Ha et al., 1987). A dieta é o fator que mais contribui para o início ou progresso de alguns tipos de câncer, assim como estudos epidemiológicos indicam que a composição da dieta pode estar relacionada com $35 \%$ das mortes por câncer em humanos, e que produtos lácteos são eficientes em retardar o desenvolvimento de tumores (Parodi, 1997).

O isômero cis-9, trans-11 tem se mostrado eficaz em reduzir a indução química de neoplasia mamária em ratos (Ip et al., 1999). Neste experimento, foi observado que, nos ratos que receberam diferentes fontes de CLA por 1 mês, pós-desmama, e posteriormente, uma dose simples de um indutor de tumor, houve inibição tanto na incidência quanto na produção do tumor. O tratamento com CLA decresceu os riscos de 
câncer mamário em aproximadamente $50 \%$, e houve uma significante incorporação de CLA no fígado, gorduras mamária e peritoneal e no plasma destes animais.

Este efeito do CLA, na inibição da carcinogênese, pode incluir redução na proliferação celular, alteração nos componentes do ciclo celular e indução da apoptose (Evans et al., 2000). Além disso modula também marcadores de imunidade e formação de eicosanóides em numerosas espécies (Belury, 2002). Ip et al. (1999) sugeriram que, em modelo animal e células de câncer de mama animal, o CLA induziu a apoptose como uma evidência na redução na expressão de um proto-oncogene antiapoptótico, o Bcl-2, em tecido mamário de ratos. O CLA induziu a apoptose em pré-adipócitos 3T3-L1 (Evans et al., 2000) e também induziu a apoptose e aumentou a expressão de oncogenes na via apoptótica dependente de p53 (i.e. p53, p21WAF1/CIP1), embora inibindo a expressão do antiapoptótico Bcl-2 em MCF-7 (i.e. células oestrogene positivas) nesta via (Wahle \& Heys, 2002). Mas, segundo estes mesmos autores, em células de câncer mamário oestrogene negativo, o CLA induziu apoptose através de uma via dependente de p53 envolvendo o aumento na expressão de p21WAF1/CIP1, Bax e Bcl-Xs. Este perfil pró-apoptótico ocorreu apesar de um acréscimo na expressão do antiapoptótico Bcl-2.

Estudos recentes têm mostrado também a influência do CLA no diabetes mellitus, agregação de plaquetas e no sistema imunológico (Sebedio et al., 1999). O efeito do CLA na prevenção e tratamento de diabetes mellitus não dependente de insulina foi primeiramente reportado por Houseknecht et al. (1998), em um experimento em que ratos Zucker graxo fa/fa pré-diabéticos, mostraram uma diminuição da tolerância à glucose e na hiperinsulinemia. Estes efeitos antidiabéticos parecem ser ligados a ativação do receptor ativado proliferador de peroxissomo (PPAR $\gamma$ ) em uma maneira similar ao thiazolidone, potente sensibilizador de insulina (i.e. tem propriedades antidiabéticas). Estes pesquisadores concluíram, portanto, que o efeito do CLA dietético na homeostase e tolerância à glucose pode ser uma importante forma terapêutica na prevenção e tratamento de diabetes mellitus não dependente de insulina.

Segundo Brown \& McIntosh (2003), afirmações sobre efeito do CLA na saúde humana ainda são inconsistentes, como, por exemplo, em relação ao consumo em que 
adultos saudáveis receberam 3-3,4 g/d de CLA por 6 meses e não foi observado efeito na porcentagem de gordura corporal e lipídios no sangue, contrastando com suplementação por 7-13 semanas com 1,4-6,8 g/g, que reduziu a massa de gordura ou a porcentagem de gordura em adultos que se exercitam, saudáveis e obesos. Esta discrepância é devido aos mecanismos específicos de cada isômero, como o trans-10, cis-12, responsável por efeitos antiadipogênicos.

O fornecimento de $3 \mathrm{~g} / \mathrm{d}$ de CLA (50\% cis-9, trans-11, 50\% trans-10, cis-12), para humanos com diabetes mellitus tipo 2, por 8 semanas, causou um efeito adverso no metabolismo da glucose e insulina, reduzindo a sensibilidade à insulina e aumentando a concentração de glucose em jejum. Enquanto foram observados efeitos positivos no fibrinogênio e metabolismo da lipoproteína de alta densidade (HDL) (Moloney et al., 2004). Contrariamente, Tricon et al. (2004) observam efeitos divergentes dos isômeros cis-9, trans-11 (0,59; 1,19 e 2,38 g/d) e do trans-10, cis-12 $(0,63 ; 1,26$ e $2,52 \mathrm{~g} / \mathrm{d})$ no perfil de lipídios do sangue de humanos saudáveis, onde o trans-10, cis-12 aumentou a razão LDL (lipoproteína de baixa densidade):HDL e HDL, enquanto o cis-9, trans-11 decresceu ambos e, nenhum isômero causou alteração na concentração de insulina plasmática. Mas cumpre sejam observadas as doses e os estádios fisiológicos de cada indivíduo. Assim, há muito ainda a ser esclarecido sobre os mecanismos de ação do CLA e seus efeitos na saúde humana.

\subsection{CLA para animais em crescimento e lactação}

Estudos do efeito do CLA, em animais em lactação, têm sido bastante observados ante a importância da concentração de gordura (i.e. principal componente energético) e proteína no leite, bem como na composição corporal de animais de interesse econômico.

Kelly et al. (1998) observaram o efeito de diferentes óleos em dietas de vacas em lactação. As dietas foram constituídas de $53 \mathrm{~g} /$ dia de óleo de amendoim (alta concentração de ácido oléico), óleo de girassol (ácido linoléico) e óleo de linhaça (ácido $\alpha$-linolênico) e administradas por duas semanas. Não foram observadas diferenças na 
produção de leite e teor de gordura do leite, mas a proteína do leite, durante o tratamento com óleo de girassol, foi maior em comparação aos demais. Entretanto, a concentração de CLA na gordura do leite, no tratamento com óleo de girassol, foi significativamente maior em relação aos demais, e aproximadamente 500\% maior que a tipicamente observada em vacas recebendo dietas tradicionais. Estes pesquisadores concluíram que a concentração de CLA no leite pode ser aumentada em dietas suplementadas com PUFA, especialmente óleos ricos em ácido linoléico. Em outras pesquisas, dietas suplementadas com CLA geraram um acréscimo no conteúdo de CLA na gordura do leite, alterando sua composição de ácidos graxos e reduzindo o teor e a produção de gordura do leite (Chouinard et al., 1999; Giesy et al., 1999; Medeiros et al., 2000).

Baumgard et al. (2000) observaram que o teor de gordura do leite diminuiu $44 \%$ devido ao efeito da infusão abomasal do CLA trans-10, cis-12 em vacas lactantes. Igualmente, um amplo decréscimo na secreção da gordura do leite (i.e. depressão da gordura do leite - DGL) foi observado com dietas com $25 \%$ de forragem e $70 \%$ de concentrado, suplementada com 5\% de óleo de soja (Piperova et al., 2000). Entretanto, Piperova et al. (2004) concluíram que a depressão de gordura no leite pode também envolver o isômero $\mathrm{C}_{18: 1}$ trans-10, embora seu efeito tenha se mostrado inferior ao do CLA trans-10, cis-12. Neste experimento, as vacas receberam dietas contendo CLA-Ca (CLA ligado a sais de cálcio, 35,83\% de trans-10, cis-12) ou isômeros do ácido graxo trans 18:1 ligado a sais de cálcio (28\% de trans-10).

Muitos trabalhos vêm sendo conduzidos também com o intuito de avaliar os efeitos do CLA na composição corporal de animais em crescimento, em suínos machos castrados (Wiegand et al., 2002), suínos em crescimento-terminação (O'Quinn et al., 2000), pós-desmama (Demaree et al., 2002) e em suínos magros geneticamente modificados (Eggert et al., 2001).

Em suínos em crescimento, um importante tecido, responsável pelo desenvolvimento do animal, é o tecido adiposo, que armazena as reservas energéticas corporais, predominantemente na forma de triacilgliceróis. A deposição de reservas, no adipócito, ocorre quando há um balanço positivo entre síntese e degradação de lipídios (Bauman \& Davis, 1975). Nesta espécie, 80\% da síntese de lipídios é feita pela via de novo, utilizando glucose como substrato, função de baixa proporção das calorias $(\sim 8 \%)$ 
da dieta na forma de ácidos graxos pré-formados. Nesta situação, cerca de $40 \%$ da utilização de glucose pelo corpo é destinada à deposição de lipídios (Etherton et al., 1995), corroborando Dunshea et al. (1992) em estudos com cinética de isótopos. Tais estudos mostraram que mais de $40 \%$ do turnover da glucose do corpo pode ser usado no tecido adiposo, para a lipogênese de novo, em suínos com $80 \mathrm{~kg}$ de peso vivo. Por conseguinte, o crescimento do tecido adiposo é altamente dependente das taxas lipogênicas e a glucose é a primeira fonte de carbono.

Assim, o efeito do CLA tem sido observado no metabolismo do tecido adiposo e na regulação da atividade das enzimas que estão presentes nos adipócitos, como a sintase de ácido graxo (FAS) e a acetil coenzima A carboxilase (ACC), consideradas entre as mais importantes. Desta forma, mudanças nas atividades destas enzimas são paralelas às mudanças nas taxas de síntese de ácidos graxos (Sinnet-Smith et al., 1979). Por conseguinte, a capacidade máxima de um tecido lipogênico carrear a síntese de novo de ácidos graxos é determinada pela concentração de enzimas lipogênicas neste tecido e, esta concentração, por sua vez, parece ser, em grande parte, determinada pela quantidade de RNAm que codifica estas enzimas (Clarke, 1993).

Alguns nutrientes e hormônios podem inibir a síntese de novo de lipídios e, conseqüentemente, alterar a composição da carcaça, diminuindo a espessura de gordura subcutânea e aumentando a deposição de tecido magro. Destes nutrientes, são os PUFAs, cuja inibição é conhecida há anos, que inibem a síntese de gordura a partir de mecanismos de curto e longo prazo. Tais ácidos graxos são conhecidos inibidores alostéricos da atividade da ACC (curto prazo) e em ratos, em crescimento, dietas ricas em PUFA reduzem a expressão da FAS (longo prazo).

Segundo Clarke \& Jump (1993), a supressão da transcrição dos genes que codificam enzimas da via de síntese de ácidos graxos, é coerente com a menor necessidade de síntese de gordura pela via de novo em animais que já apresentam altas taxas de síntese de gordura a partir de ácidos graxos pré-formados. Além da atividade das enzimas limitantes, outro sistema que pode ser alterado é o de transporte de glucose na membrana celular, o qual é controlado por hormônios homeorréticos e homeostáticos (Bauman \& Vernon, 1993). 
A partição de nutrientes e o decréscimo da síntese de gorduras são os efeitos biológicos relacionados com o CLA e têm sido apresentados, por diversos autores, que causam aumento na eficiência alimentar de suínos (Bee, 2000; Dugan et al., 1999; Dugan et al., 1997; Ostrowska et al., 1999; Thiel-Cooper et al., 2001). Entretanto, os efeitos do CLA na composição da carcaça e taxas de deposição nos tecidos em suínos, ainda não estão bem reportados, pois o mecanismo exato pelo qual o CLA atua no metabolismo de lipídios não está totalmente elucidado.

Dugan et al. (1997) testaram o efeito do CLA nas características da carcaça de suínos de 61,5 a $106 \mathrm{~kg}$ de peso vivo, os quais receberam 2\% de CLA ou 2\% de óleo de girassol. Estes autores observaram um aumento na deposição de tecido magro (+2,3\%) e redução na deposição de gordura subcutânea $(-6,8 \%)$, além da incorporação de CLA no tecido adiposo (3-4,7\% do total de lipídios). Estes resultados foram corroborados pelo mesmo grupo em 1999, mas acrescentaram que não houve alteração na qualidade e palatabilidade da carne dos suínos que receberam dieta com CLA.

Dunshea et al. (1998), suplementando marrãs com níveis crescentes de 0;0,125; 0,25; 0,5; 0,75 e $1 \%$ de CLA, observaram diminuição na espessura de toucinho de $21 ; 17,1$; 16,$1 ; 16,9 ; 15,4$ e 14,6 mm, respectivamente, sem alterar o consumo e melhorando o ganho de peso e conversão alimentar. Bee (2000) observou que a adição de $2 \%$ de um produto contendo CLA (58,9\% do total de ácidos graxos) na dieta de matrizes, aumentou o ganho de peso e ingestão nos leitões pós-desmama, em relação às mães que receberam somente $2 \%$ de LA, independentemente da dieta inicial que os leitões receberam.

Os efeitos de dietas suplementadas com CLA, na composição da carcaça de suínos em crescimento, foram relacionados às taxas de acréscimo de gordura, proteína, água e matéria mineral, e a inclusão de produto contendo CLA (55\% do total de AG), na dieta, também aumentou a deposição de tecido magro e decresceu a deposição de gordura em aproximadamente 31\% (Ostrowska et al., 1999). Posteriormente, Ostrowska et al. (2003b) confirmaram estes efeitos do CLA em diminuir a deposição de gordura em suínos, medida por absorção em raio-X de dupla energia e, também, aumentar o conteúdo de CLA no tecido adiposo destes animais (Ostrowska et al., 2003a).

Thiel-Cooper et al. (2001) verificaram, em suínos suplementados com mistura de ácidos graxos contendo CLA na dieta $(60,5 \%$ do total de AG), um aumento linear no 
ganho médio diário com as diferentes concentrações de CLA $(0,0,12,0,25,0,5$ e 1\%), mas o consumo não foi afetado. Quando realizada a análise por ultra-som da área de olho de lombo, na $10^{\mathrm{a}}$ costela, estes animais apresentaram menor espessura de gordura em relação ao grupo controle. A dissecação do lombo demonstrou que o CLA produziu um efeito quadrático em ambas, gordura intermuscular e subcutânea. Estes autores concluíram que o CLA da dieta foi incorporado nos tecidos de suínos e teve efeito positivo na performance e composição corporal.

\subsection{Regulação da expressão gênica}

Se o CLA altera o metabolismo lipídico de um modo geral, isto se deve ao seu efeito direto ou não na regulação gênica, seja no RNAm ou na atividade de enzimas e fatores de transcrição, seja na modificação do metabolismo como um todo. Assim, pesquisas relacionadas têm buscado avaliar o efeito do CLA na regulação de genes responsáveis pelo aumento e/ou diminuição da síntese, deposição e mobilização de ácidos graxos e também genes relacionados ao metabolismo da glucose. Neste metabolismo, o transportador de glucose-4 (Glut 4) tem papel relevante pois afeta a entrada deste substrato para a célula. Por exemplo, Takahashi et al. (2002) observaram uma redução no RNAm do Glut 4 no tecido adiposo marrom e branco de camundongos que receberam CLA, durante 21 dias.

Satory \& Smith (1999) observaram que o CLA promoveu o acúmulo de lipídios pela via de novo em pré-adipócitos 3T3-L1, enquanto Park et al. (1997) utilizando a mesma linhagem celular, verificaram redução de 66\% na atividade da LPL e na concentração intracelular de triacilgliceróis (-8\%) e glicerol (-15\%). Entretanto, houve um aumento no glicerol livre no meio de cultura $(+22 \%)$. Contudo, não observaram redução na atividade da FAS. Neste mesmo experimento, em camundongos recebendo dieta suplementada com CLA, obsevaram um aumento na atividade da carnitina palmitoil transferase (CPT) no tecido muscular e adiposo. Este aumento sugere um aumento de oxidação lipídica e que o CLA pode ter causado uma inibição na produção do metabólito intermediário na síntese lipídica, o malonil CoA, que é um regulador negativo da CPT. A quantidade de malonil CoA, por sua vez, é regulada pela ACC2 
(isoforma 2) no músculo e ACC1 (isoforma 1) no fígado e no tecido adiposo (AbuElheiga et al., 2001).

Park et al. (1999) observaram redução na atividade da LPL, em culturas de adipócitos 3T3-L1. Efeito este notado somente pela ação do isômero trans-10, cis-12, sem ter sido influenciado pelo CLA cis-9, trans-11. Entretanto, para se determinar se o efeito na atividade da LPL foi direto ou por meio de um metabólito, Park et al. (1999) e Park \& Pariza (2001) prepararam um cognato, o ácido nonadecadienóico conjugado (CNA), e observaram uma inibição na atividade da LPL e acúmulo de lipídio em 3T3-L1 similar ao CLA. Presumiram, que o CNA, por diferir em comprimento por um átomo de carbono, é metabolizado diferentemente do CLA. Concluíram, portanto, que a inibição da atividade da LPL, no sistema celular, é devido diretamente ao composto administrado e não ao metabólito gerado por esse composto.

Posteriormente, trabalho conduzido por Xu et al. (2003) confirmou esses efeitos. No tecido adiposo parametrial de camundongos, suplementados com 0,5 g de CLA/g de peso vivo, houve uma significativa redução na atividade da lipoproteína lipase liberando heparina e da LPL intracelular, bem como uma redução na transformação de glucose a $\mathrm{CO}_{2}$, ácido graxo e glicerol. Entretanto, o CLA não pareceu elevar a lipólise no tecido adiposo desses animais.

Sakono et al. (1999) compararam o efeito de dietas contendo CLA e LA na produção de corpos cetônicos e secreção de lipídios, em ratos, observando que somente a dieta contendo CLA enriqueceu a oxidação hepática de ácidos graxos e estimulou a produção de corpos cetônicos, em comparação com dietas contendo, também, LA. O CLA aumentou igualmente a atividade mitocondrial da CPT, no tecido adiposo epididimal e no músculo, sugerindo que o CLA influencia o metabolismo de ácidos graxos não só no fígado mas em todos os tecidos extra-hepáticos.

Um dos efeitos do CLA na homeostase lipídica é via ativação do PPAR (MoyaCamarena \& Belury, 1999) e, segundo Mersmann (2001), os CLAs são ligantes para o PPAR. Entretanto, Ding et al. (2000) não observaram alteração na concentração do RNAm do PPAR $\gamma$, na diferenciação in vitro de adipócitos de suínos tratados com CLA, enquanto houve um acréscimo na atividade da LPL. Contrariamente, Meadus et al. 
(2002) verificaram um aumento nas taxas de RNAm do PPAR $\gamma$ e proteína ligante ao ácido graxo do adipócito (AFABP) em suínos castrados alimentados com CLA por 45 dias, mas este aumento no RNAm não foi observado para o PPAR $\alpha$.

O efeito do CLA nas enzimas envolvidas no metabolismo lipídico, dentre elas as responsáveis pela síntese de novo de ácidos graxos, reesterificação de ácidos graxos e do ciclo das pentoses fosfato (i.e. produção de NADPH), vem sendo pesquisado. Peterson et al. (2003), administrando dieta que induz a DGL em vacas, observaram uma redução de 25 e $27 \%$ na porcentagem e produção de gordura do leite, respectivamente, e também um aumento da concentração do isômero trans-10, cis-12 no leite. Estas observações corroboraram alterações na abundância do RNAm de enzimas lipogênicas, como ACC, FAS, acil-CoA ligase, glicerol fosfato acil-transferase (GPAT) e acilglicerol fosfato aciltransferase (AGPAT). As reduções nos RNAs mensageiros também foram correlacionadas ao aparecimento do CLA trans-10, cis-12 na gordura do leite para a ACC, FAS, LPL e GPAT, concluindo, portanto, que dietas que induzem DGL envolvem efeitos coordenados no RNAm para a via de síntese lipídica e dão suporte a alterações nos mecanismos envolvidos na ativação transcricional desses genes.

O efeito do CLA, na atividade da ACC e da FAS, foi observado em vacas que receberam dietas que causam DGL (Piperova et al., 2000). A administração desta dieta causou um decréscimo de $43 \%$ na secreção da gordura do leite e de 61 e $44 \%$ na atividade da ACC e FAS, respectivamente, consistente com a redução na abundância do RNAm da ACC. Corroborando estes dados, Hayashi (2003) observou uma redução na atividade da FAS, da G-6PDH e da 6-PGDH no fígado e na glândula mamária de ratas que receberam ração contendo CLA-60 (35\% trans-10, cis-12) de 13-15 dias pós-parto. No tecido adiposo, somente a atividade da FAS foi reduzida. Contrariamente, Lin et al. (2004) observaram uma redução na atividade e abundância do RNAm da ACC na glândula mamária de ratas lactantes que receberam CLA de 4 a 15 dias pós-parto. Entretanto, para a FAS, só foi observada redução na abundância do RNAm. Por outro lado, no fígado destes mesmos animais, a atividade e a abundância RNAm da ACC e da FAS não foram afetadas. 
Choi et al. (2000), tratando pré-adipócitos 3T3-L1 em diferenciação com CLA trans-10, cis-12, observaram redução dose-dependente na expressão (i.e. RNAm) da SCD1. Entretanto, a expressão de outros genes dos adipócitos, como P2 adiposo (aP2), FAS, SCD2 e PPAR $\gamma$, permaneceu elevada. Baumgard et al. (2001) também mostraram efeito do CLA trans-10, cis-12 na expressão da SCD, avaliada pela sua atividade enzimática.

Trabalhos realizados com suínos demonstraram que houve um decréscimo na atividade da SCD e no índice da $\Delta^{9}$-dessaturase no tecido adiposo, após suplementação in vivo com CLA (Gatlin et al., 2002; Smith et al., 2002). A presença de CLA, na dieta inicial dos leitões, aumentou a atividade da glucose 6-fosfato desidrogenase (G-6PDH) e da NADP-malato desidrogenase (NADP-MD) no tecido adiposo, mas não causou mudanças na atividade da FAS. Bee (2000) observou, todavia, que a atividade da FAS foi maior na gordura omental do que na subcutânea, o que pode ser explicado pela diferença da proporção de gordura entre os dois tecidos. Entretanto, a composição de ácidos graxos foi de alguma maneira contraditória à atividade da FAS. Contraditoriamente, Corino et al. (2003), trabalhando com suínos suplementados com CLA, não observaram diminuição na atividade da NADP-MD e G-6PDH no tecido adiposo, mas houve uma queda na atividade da ACC. Em um trabalho anterior, este mesmo grupo observou redução na atividade da ACC no fígado e no tecido adiposo de coelhos que receberam dieta suplementada com CLA (Corino et al., 2002). 


\section{VALIDAÇÃO DO USO DE PVA COMO CARREADOR DE ÁCIDOS GRAXOS EM CULTURA DE EXPLANTES DE TECIDO ADIPOSO}

\section{Resumo}

Culturas de explantes de tecido adiposo são uma ferramenta para estudo dos mecanismos intracelulares de ação de hormônios e nutrientes. Entretanto, a avaliação dos efeitos de lipídios, nestas culturas, necessita de uma molécula carreadora de ácidos graxos. A albumina sérica bovina (BSA) tem sido usada com este propósito, mas estudos sugerem que a presença de contaminantes afeta a resposta celular, particularmente a lipogênese. O objetivo deste trabalho foi testar o uso da BSA e validar a utilização de poliivinil álcool (PVA) como macromolécula carreadora de ácido graxo, testando seu efeito no sistema de cultura. Explantes de tecido adiposo de nove suínos, em crescimento, $(78 \pm 3 \mathrm{~kg}$ ) foram submetidos à cultura em meio 199 (com adição de 100 $\mathrm{ng} / \mathrm{mL}$ de insulina, $10 \mathrm{nM}$ de dexametasona e antibióticos) por 4, 12, 24 e 48 horas, com os tratamentos: a) Controle - meio 199 ; b) PVA - meio 199 com $100 \mu \mathrm{M}$ de PVA e c) pGH - meio 199 com 100 ng/mL de pGH (hormônio do crescimento suíno) e $100 \mu \mathrm{M}$ de PVA. Após cada período de cultura, explantes foram coletados e submetidos ao ensaio de lipogênese (taxa de incorporação de glucose marcada com ${ }^{14} \mathrm{C}$ em $2 \mathrm{~h}$ de incubação em tampão Krebs-Ringer na presença e ausência de insulina). Após 48 h, em meio 199 os explantes foram analisados para lipólise (taxa de liberação de ácidos graxos não esterificados - AGNE - em $2 \mathrm{~h}$ de incubação em tampão Krebs-Ringer na presença e ausência de isoproterenol). Nos ensaios preliminares, foram utilizadas diferentes fontes 
comerciais e lotes de BSA, que provocaram alterações nas taxas lipogênicas. Diferentemente da BSA, o PVA não alterou a síntese de lipídios, sendo que o controle positivo $(\mathrm{pGH})$ diminuiu a incorporação de glucose em lipídios $(\mathrm{P}<0,01)$ em relação ao Controle e também ao PVA $(\mathrm{P}<0,05)$. Para a lipólise, também, não houve diferença entre Controle e PVA, entretanto houve efeito do pGH que aumentou a lipólise em relação ao Controle $(\mathrm{P}<0,10)$ e ao PVA $(\mathrm{P}<0,05)$. Os resultados deste trabalho confirmam que diferentes lotes de BSA alteram a taxa de síntese de lipídios em cultura, sugerindo que não se deva utilizar a BSA, como carreador de ácidos graxos, para sistemas em cultura. Já o PVA não alterou as taxas de lipólise, lipogênese, nem a resposta à insulina em relação ao Controle. Portanto, a substituição da BSA pelo PVA nos parece indicada na realização de estudos de ácidos graxos em cultura de tecido.

\section{VALIDATION OF THE USE OF PVA AS FATTY ACID CARRIER IN CULTURE OF ADIPOSE TISSUE EXPLANTS}

\section{Summary}

Cultures of adipose tissue explants are a tool for study of the intracellular mechanisms of hormones and nutrient action. However, evaluation of the effects of fatty acids in these cultures require the use of a carrier molecule. Bovine serum albumin (BSA) has been used with this purpose, but several studies suggest that the presence of contaminants can alter cellular responses including the lipogenesis. The objective of this study was evaluate the use of BSA and to validate the use of polyvinyl alcohol (PVA) as a carrier. Adipose tissue explants from nine growing pigs $(78 \pm 3 \mathrm{~kg})$ were cultured in medium 199 (with $100 \mathrm{ng} / \mathrm{mL}$ insulin, $10 \mathrm{nM}$ dexamethasone and antibiotics) for 4, 12, 24 and 48 hours. Treatments were Control - medium 199; PVA - medium 199 plus 100 $\mu \mathrm{M}$ of PVA and pGH - medium 199, $100 \mathrm{ng} / \mathrm{mL}$ of pGH (porcine growth hormone) plus $100 \mu \mathrm{M}$ of PVA. After each culture period explants were collected and assayed for 
lipogenesis (measured as rates of ${ }^{14} \mathrm{C}$ labeled glucose incorporation over a subsequent 2 $\mathrm{h}$ incubation in Krebs-Ringer in presence or absence of insulin). After $48 \mathrm{~h}$ in medium 199 samples were also analyzed for lipolysis (non-esterified fatty acid release - NEFAover a subsequent $2 \mathrm{~h}$ incubation in Krebs-Ringer in presence or absence of isoproterenol). Preliminary studies confirmed a significant effect of different commercial sources and lots of BSA on lipogenesis. Conversely, there were no effects of PVA on basal or insulin stimulated lipid synthesis. Glucose incorporation was significantly decreased $(\mathrm{P}<0.01)$ in response to a positive control $(\mathrm{pGH})$ compared to both a Control and to PVA $(\mathrm{P}<0.05)$. For lipolysis, once again there were no effects of PVA, but the system was responsive to the positive control of pGH. GH treatment was different from Control $(\mathrm{P}<0.10)$ and PVA $(\mathrm{P}<0.05)$. Distinctly from BSA, the use of PVA in adipose tissue cultures did not alter liplytic and lipogenic responses. Therefore, the substitution of BSA for PVA is an alternative for studies with bioactive fatty acids using adipose tissue culture systems.

\subsection{Introdução}

As culturas de explantes de tecido adiposo são uma ferramenta para estudo dos mecanismos intracelulares de ação de hormônios e nutrientes, incluindo ácidos graxos. Culturas de tecidos permitem a condução de diversos tratamentos simultâneos e, consequientemente, de muitos estudos de forma rápida e de baixo custo. Entretanto, para a avaliação dos efeitos dos ácidos graxos nestas culturas, há a necessidade de uma molécula carreadora destas moléculas. A albumina sérica bovina (BSA) tem sido usada com este propósito, mas há na literatura estudos sugerindo que a presença de contaminantes afeta a resposta celular (Walton \& Etherton, 1986) bem como mascara os efeitos dos ácidos graxos (Tronstad et al., 2001).

$\mathrm{Na}$ literatura, existem, também, diferenças na metodologia recomendada para formação do complexo ácido graxo (AG):BSA tanto na temperatura, proporção de AG:BSA como no período em que o complexo permanece para ser formado (Brown et 
al., 2001; Evans et al., 2002; Mahoney et al., 1977; Matitashvili et al., 2001; Park et al., 1997).

Existem diversas metodologias para cultura do tecido adiposo. Estas culturas podem utilizar linhagens de células (e.g. linhagens de pré-adipócitos 3T3-L1) ou sistema de culturas primárias (e.g. explantes ou células isoladas). Cada modelo de cultura utilizado tem suas vantagens e desvantagens e, muitas vezes, estas diferenças dificultam a comparação dos resultados obtidos. O uso de culturas primárias de suínos, na forma de explantes, tem sido utilizado com grande sucesso na avaliação do efeito de diferentes hormônios e nutrientes sobre a taxa de lipogênese (Dunshea et al., 1992; Etherton \& Bauman 1998; Etherton et al., 1995; Lanna et al., 1994). Nesta espécie a síntese de gorduras ocorre no próprio tecido adiposo, sendo que cerca de $80 \%$ dela é feita pela via de novo.

O objetivo deste trabalho foi validar a utilização de poliivinil álcool (PVA), como macromolécula carreadora de ácido graxo, testando a hipótese de que este composto não altera o metabolismo das células em cultura. Esta avaliação foi realizada medindo-se a taxa de lipogênese e a taxa de lipólise.

\subsection{Material e Métodos}

\subsubsection{Culturas de explantes de tecido adiposo de suínos}

Nove suínos Landrace x Large White, do Departamento de Zootecnia ESALQ/USP, com peso médio de $78+$ ou $-3 \mathrm{~kg}$, foram utilizados. Aproximadamente $20 \mathrm{~g}$ de tecido adiposo subcutâneo foram coletados da região dorsal posterior do pernil e, imediatamente, colocados no tampão de transporte (25 mM de HEPES; 0,15 M de NaCl; $20 \mathrm{U} / \mathrm{mL}$ de penicilina; $20 \mu \mathrm{g} / \mathrm{mL}$ de estreptomicina; $5 \mu \mathrm{g} / \mathrm{mL}$ de neomicina e 2,5 $\mu \mathrm{g} / \mathrm{mL}$ de anfotericina B - Sigma; $\left.37^{\circ} \mathrm{C}, \mathrm{pH} 7,4\right)$. Explantes de 50-100 mg foram preparados a partir da camada intermediária do tecido subcutâneo, em condições 
assépticas, e incubados em meio 199 (25 mM de HEPES; $25 \mathrm{mM}$ de bicarbonato; 20 $\mathrm{U} / \mathrm{mL}$ de penicilina; $20 \mu \mathrm{g} / \mathrm{mL}$ de estreptomicina; $5 \mu \mathrm{g} / \mathrm{mL}$ de neomicina e $2,5 \mu \mathrm{g} / \mathrm{mL}$ de anfotericina B - Sigma; $\left.37^{\circ} \mathrm{C}, \mathrm{pH} 7,4\right)$ de acordo com metodologia descrita por Lanna et al. (1995). Ao meio de cultura foram adicionados os tratamentos: a) Controle - 100 $\mathrm{ng} / \mathrm{mL}$ de insulina e $10 \mathrm{nM}$ de dexametasona; b) PVA - $100 \mathrm{ng} / \mathrm{mL}$ de insulina, $10 \mathrm{nM}$ de dexametasona e $100 \mu \mathrm{M}$ de poliivinil álcool (PVA - Sigma) e c) pGH - $100 \mathrm{ng} / \mathrm{mL}$ de insulina, $10 \mathrm{nM}$ de dexametasona, $100 \mathrm{ng} / \mathrm{mL}$ de pGH (hormônio do crescimento recombinante suíno - Reporcin ${ }^{\circledR}$, Southern Cross Biotech) e $100 \mu \mathrm{M}$ de PVA. As placas foram mantidas em atmosfera contendo $95 \%$ Ar: $5 \% \mathrm{CO}_{2}$ a $37^{\circ} \mathrm{C}$ por $4,12,24$ e 48 horas.

Após esses períodos de incubação, parte dos explantes foi coletada e imediatamente submetida às incubações de lipogênese. E, após 48 horas, parte dos explantes foi imediatamente submetida ao ensaio de lipólise.

\subsubsection{Ensaio de Lipogênese}

Após cada período de cultura, os explantes foram coletados e transferidos para frascos de cintilação contendo $2 \mathrm{~mL}$ de meio de lipogênese (KRB 1X - Krebs Ringer buffer - 0,65 mM de $\mathrm{CaCl}_{2} ; 10 \mathrm{mM}$ de HEPES; $10 \mathrm{mM}$ de glucose e 0,5 $\mu \mathrm{Ci} / \mathrm{mL}$ de glucose D-[ $\left[{ }^{14} \mathrm{C}(\mathrm{U})\right]$ - Amersham Biosciences; pH 7,4 a $\left.37^{\circ} \mathrm{C}\right)$, sob atmosfera de $95 \%$ $\mathrm{O}_{2}: 5 \% \mathrm{CO}_{2}$, sob agitação, por 2 horas, a $37^{\circ} \mathrm{C}$. Foram realizadas incubações em triplicatas com: a) Lipogênese Basal - sem adições e b) Lipogênese INS - estimulada com $1000 \mathrm{ng} / \mathrm{mL}$ de insulina.

Posteriormente, os explantes foram submetidos às extrações de lipídios, segundo Folch et al. (1957), com modificações. Os explantes foram transferidos para frascos de extração contendo $5 \mathrm{~mL}$ de metanol:clorofórmio 1:2. Após permanecerem em descanso por 1 hora, adicionou-se $1 \mathrm{~mL}$ de $\mathrm{NaCl} 1 \%$ e a extração prosseguiu por 12 a 16 horas. À fase inferior, foram adicionados $0,5 \mathrm{~mL}$ de hexano e $5 \mathrm{~mL}$ de líquido de cintilação (Sigma). Os frascos de cintilação foram encaminhados para o Laboratório de Experimentação Nuclear, CENA/USP, para leitura em cintilador automático (Beckman 
Instruments- LS 5000 TD - Liquid Scintillation System) e a lipogênese expressa em nanomoles de glucose incorporada por grama de tecido por 2 horas.

\subsubsection{Ensaio de lipólise}

Após o período de cultura de 48 horas, os explantes foram coletados e incubados em $2 \mathrm{~mL}$ de meio de lipólise (KRB 1X - 0,65 mM de $\mathrm{CaCl}_{2} ; 2,5 \mathrm{mM}$ de HEPES; 5,6 $\mathrm{mM}$ de glucose e $3 \%$ de $\mathrm{BSA}$; $\mathrm{pH} 7,4$ a $37^{\circ} \mathrm{C}$ ), sob atmosfera de $95 \% \mathrm{O}_{2}: 5 \% \mathrm{CO}_{2}$, sob agitação, por 2 horas, a $37^{\circ} \mathrm{C}$. Foram realizadas triplicatas das incubações com: a) Lipólise Basal - sem adições e b) Lipólise ISO - lipólise estimulada com $10^{-5} \mathrm{M}$ de isoproterenol. Após este período, alíquotas dos meios foram coletadas para análise de AGNE. A concentração de AGNE foi determinada por método enzimático colorimétrico, a $540 \mathrm{~nm}$, utilizando-se o kit NEFA $C^{\circledR}$ (Wako Chemicals),. As leituras de absorbância foram realizadas no Laboratório de Biologia Molecular de Plantas, ESALQ/USP, em Leitor de Elisa (Spectra Max Plus - Molecular Devices), utilizando-se microplacas com poços de $200 \mu \mathrm{L}$ onde foram adicionadas amostras, padrões e reagentes. Os valores de absorbâncias foram convertidos em concentração ( $\mu$ mol de ácido oléico/L) através da curva-padrão determinada e as concentrações de AGNE obtidas foram corrigidas para o peso, em gramas, de cada explante e expressas em $\mu$ moles de ácido oléico por g de tecido por 2 horas.

\subsubsection{Análise estatística}

Análises estatísticas foram realizadas utilizando-se o Proc Mixed (SAS, 1999). Para análise de variância do ensaio de lipogênese, com medidas repetidas no tempo, foi utilizado um modelo envolvendo os efeitos fixos de tratamentos, estímulo, tempo e suas interações e efeitos aleatórios de animal dentro do tratamento e animal dentro do tratamento*estímulo que foram os erros para testar efeito de tratamento e de estímulo, respectivamente. Tendo em vista que o tempo não foi igualmente espaçado, usou-se 
estrutura de covariância do tipo SP(POW) (tempo), conforme recomendado (Littel et al., 1996).

No ensaio de lipólise, a análise de variância foi feita de acordo com o modelo de experimento com parcela subdividida, tendo tratamentos aplicados nas parcelas e estímulo às subparcelas. Todas as comparações de médias foram feitas pelo teste de Tukey.

\subsection{Resultados e Discussão}

Em ensaios preliminares, utilizando albumina sérica bovina (BSA - fração V, fatty acid free) em meio de cultura, foram observadas variações nas respostas lipogênicas. Houve uma tendência de maior taxa de incorporação de glucose após 24 (Figura 1) e $48 \mathrm{~h}$ em meio de cultura contendo BSA, insulina e dexametasona, comparado ao meio contendo apenas insulina e dexametasona. As diferenças encontradas nos ensaios preliminares sugerem que a BSA não deve ser utilizada como carreador de ácidos graxos em experimentos onde a taxa de lipogênese deva ser estudada.

Foram testadas diferentes fontes comerciais, lotes e concentrações de BSA. Para a maioria das fontes comerciais e lotes, houve algum nível de alteração das respostas lipogênicas na presença de BSA. Também foi testada uma albumina previamente submetida à purificação por diálise (Spector, 1986) o que também não resolveu a questão de estimulação da síntese de lipídios. Como é impossível submeter a fonte de BSA a estes testes antes de cada experimento, sugeriu-se a utilização do PVA. 


\section{Lipogênese após 24 h de cultura}

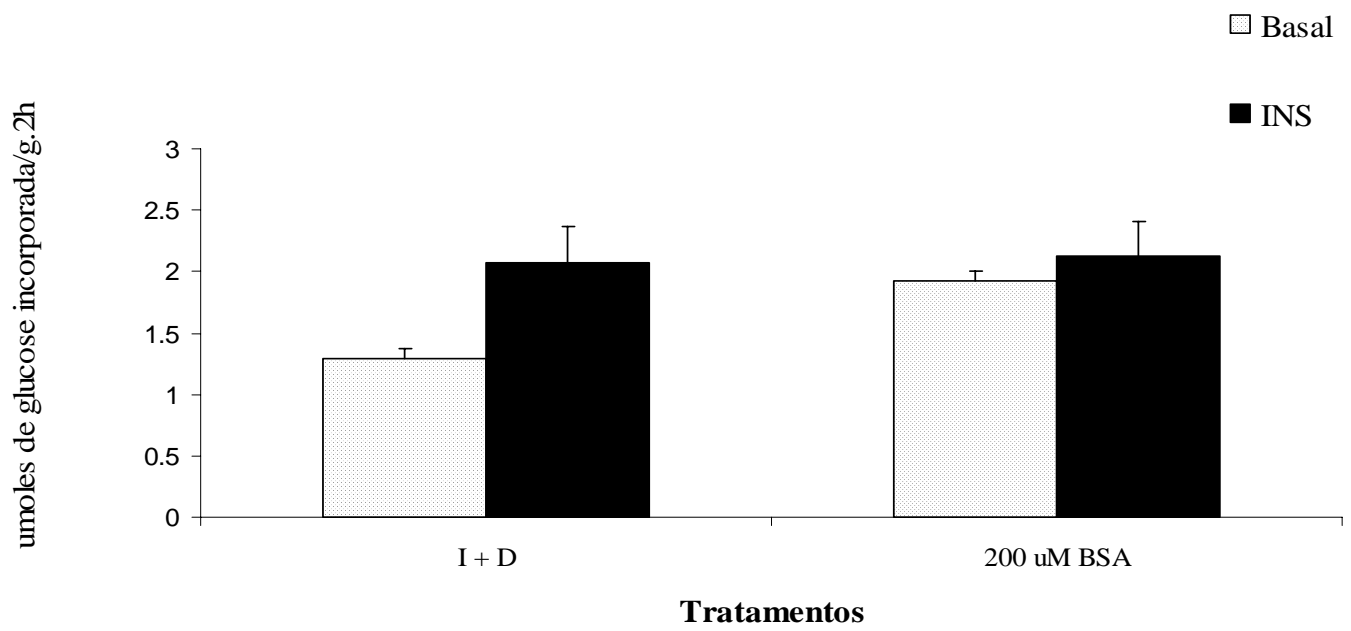

Figura 1 - Lipogênese em explantes de tecido adiposo após $24 \mathrm{~h}$ de cultura com I+D (insulina e dexametasona) ou $200 \mu \mathrm{M}$ BSA (insulina, dexametasona e albumina sérica bovina). Resultados expressos em $\mu$ moles de ${ }^{14} \mathrm{C}$-glucose incorporada por $\mathrm{g}$ de tecido após $2 \mathrm{~h}$ de incubação sem adições (Basal) ou com $1000 \mathrm{ng} / \mathrm{mL}$ de insulina (INS)

Consistentes com os dados da Figura 1, Walton \& Etherton (1986) afirmam que a adição de BSA, em quantidades elevadas pode alterar o efeito da insulina em estimular a lipogênese no tecido adiposo de suínos. Estes mesmos autores observaram diferenças entre fontes comerciais de BSA nos seus efeitos sobre a lipogênese. Foram utilizadas incubações de explantes de tecido adiposo de suínos, por 2 horas, semelhantes ao do presente trabalho. Os autores sugerem ainda que contaminantes nos preparados comerciais incluem o IGF (fatores de crescimento semelhantes à insulina) e esteróides entre outros. Estes resultados levaram à tentativa de encontrar outra molécula carreadora. A alternativa testada foi a troca da BSA pelo PVA.

Os resultados do efeito PVA, na incorporação de glucose marcada com ${ }^{14} \mathrm{C}$, estão na Tabela 1. Não foi detectado efeito para as interações: tratamento*estímulo $(\mathrm{P}=0,77)$, 
tratamento*tempo $(\mathrm{P}=0,28)$, tempo*estímulo $(\mathrm{P}=0,79)$ e tempo*tratamento*estímulo $(\mathrm{P}=0,85)$. Entretanto, foram detectados efeitos para tratamento $(\mathrm{P}<0,001)$, tempo $(\mathrm{P}<0,001)$ e para Basal: 4803,26 e Insulina 5950,20 nanomoles de glucose incorporada/g.2h $(\mathrm{P}<0,05)$. 
Tabela 1. Taxas de lipogênese em explantes de tecido adiposo, após 4, 12, 24 e 48 horas de cultura com diferentes tratamentos

\begin{tabular}{|c|c|c|c|c|}
\hline & \multicolumn{4}{|c|}{ TRATAMENTOS ${ }^{1}$} \\
\hline & & $\mathbf{C}$ & PVA & pGH \\
\hline & & \multicolumn{3}{|c|}{ nanomoles de glucose incorporada/g.2h } \\
\hline \multirow[t]{2}{*}{4} & Basal & 7726,7 & 8272,5 & 4992,5 \\
\hline & INS & 9373,1 & 1003 & 7163,2 \\
\hline \multirow[t]{2}{*}{12} & Basal & 5923,4 & 5017,3 & 5003,7 \\
\hline & INS & 7286,2 & 6352,8 & 6238,9 \\
\hline \multirow[t]{2}{*}{24} & Basal & 5496,4 & 5389,0 & 3225,7 \\
\hline & INS & 8698,8 & 6901,3 & 5753,6 \\
\hline \multirow[t]{2}{*}{48} & Basal & 3347,9 & 2231,8 & 1660,3 \\
\hline & INS & 4997,3 & 2911,4 & 1500,2 \\
\hline \multicolumn{2}{|c|}{ Lipogênese $^{3}$} & $\mathbf{6 4 0 9 , 6}(1090,7)$ & $\mathbf{5 9 1 4 , 4}(1090,7)$ & $\mathbf{3 8 0 4 , 6}(1112,8)$ \\
\hline \multicolumn{5}{|c|}{ EFEITOS $^{4}$} \\
\hline \multicolumn{2}{|c|}{$\mathrm{C} \times \mathrm{PVA}$} & \multicolumn{2}{|c|}{$\mathrm{C} \times \mathrm{pGH}$} & PVA x pGH \\
\hline \multicolumn{2}{|c|}{ ns } & \multicolumn{2}{|c|}{$* *$} & * \\
\hline
\end{tabular}

${ }^{1}$ Tratamentos: C: controle (100 ng/mL de insulina e $10 \mathrm{nM}$ de dexametasona); PVA: $100 \mu \mathrm{M}$ de PVA e pGH: $100 \mathrm{ng} / \mathrm{mL}$ de $\mathrm{pGH}$.

${ }^{2}$ Tempo: após 4, 12, 24 e 48 horas de cultura.

${ }^{3}$ M: média do Basal: (sem adição) e INS: (1000 ng/ml de insulina).

${ }^{4}$ Lipogênese: médias e seus respectivos erros-padrão, em nanomoles de glucose incorporada por $\mathrm{g}$ de tecido após $2 \mathrm{~h}$ de incubação, das culturas de explante de tecido adiposo de 9 animais.

${ }^{5}$ Probabilidade das diferenças entre tratamentos $(* \mathrm{P}<0,05 ; * * \mathrm{P}<0,01 ; \mathrm{ns}: \mathrm{P}>0,10)$. 
$\mathrm{Na}$ Tabela 1 observa-se que a taxa de incorporação da glucose- $-{ }^{14} \mathrm{C}$ em lipídios para o tratamento com pGH foi menor do que para os demais. Esta redução é consistente com a observada em diversos estudos com hormônio do crescimento. Os resultados deste controle positivo demonstram que o sistema de cultura utilizado estava metabolicamente ativo e respondendo adequadamente aos estímulos hormonais.

Para os tratamentos C e PVA não houve diferença para a taxa de síntese lipídica $(\mathrm{P}=0,73)$, consistente com a hipótese proposta de que o PVA não altera o metabolismo lipídico em culturas primárias de explantes do tecido adiposo. Os valores de $\mathrm{P}$ para as comparações entre $\mathrm{C}$ e pGH, bem como entre PVA e pGH, também são consistentes com a hipótese deste trabalho. O efeito do pGH é observado mesmo com a adição de PVA ao meio, demonstrando que este componente não afeta as respostas a este hormônio, nem a atividade de síntese lipídica ao longo dos diferentes tempos de incubação. Entretanto, não pode deixar de ser notar que houve uma elevada variação nestes parâmetros.

Os valores de lipólise (i.e. liberação de ácidos graxos não esterificados, após $2 \mathrm{~h}$ de incubação), observados na Tabela 2, demonstram que não houve diferença entre os tratamentos C e PVA $(\mathrm{P}=0,92)$. Foram detectados efeitos para tratamento $(\mathrm{P}<0,01)$, estímulo $(\mathrm{P}<0,001)$. Entretanto, não houve significância estatística para a interação tratamento*estímulo $(\mathrm{P}=0,44)$. 
Tabela 2. Taxas de lipólise (liberação de ácidos graxos em 2 h de incubação) em explantes de tecido adiposo mantidos em cultura por 48 horas sob diferentes tratamentos

TRATAMENTOS

\begin{tabular}{|c|c|c|c|c|}
\hline & $\mathbf{C}$ & PVA & pGH & $\mathbf{M}^{2}$ \\
\hline \multicolumn{5}{|c|}{ rmoles de AGNE/g.2 h } \\
\hline \multicolumn{5}{|l|}{ Estímulo $^{3}$} \\
\hline BASAL & $1,75(0,85)$ & $1,85(0,90)$ & $3,65(0,85)$ & 2,41 \\
\hline ISO & $7,29(0,90)$ & $4,73(1,70)$ & $9,05(0,90)$ & 7,02 \\
\hline \multicolumn{5}{|c|}{ EFEITOS ${ }^{4}$} \\
\hline C x PVA & & $\mathrm{C} \times \mathrm{pGH}$ & & PVA x pGH \\
\hline ns & & $\dagger$ & & $*$ \\
\hline
\end{tabular}

${ }^{1}$ Tratamentos: C: controle (100 ng/mL de insulina e $10 \mathrm{nM}$ de dexametasona); PVA: $100 \mu \mathrm{M}$ de PVA e pGH: $100 \mathrm{ng} / \mathrm{mL}$ de $\mathrm{pGH}$.

${ }^{2}$ M: média da lipólise Basal: (sem adição) e ISO: $\left(10^{-5} \mathrm{M}\right.$ de isoproterenol).

${ }^{3}$ Valores médios e dos erros-padrão de lipólise em $\mu$ moles de AGNE por g de tecido por $2 \mathrm{~h}$ de incubação com os estímulos, após $48 \mathrm{~h}$ de cultura nos diferentes para cada tratamento.

${ }^{4}$ Probabilidade das diferenças entre tratamentos $\left(* \mathrm{P}<0,05 ;{ }^{\dagger} \mathrm{P}<0,10 ; \mathrm{ns}: \mathrm{P}>0,10\right)$.

A falta de interação tratamento*estímulo mostra que os explantes responderam aos tratamentos independentemente do estímulo. O tratamento com pGH induziu a um aumento da mobilização de AGNE, com e sem isoproterenol ( $\beta$-adrenérgico), o que corrobora seu efeito em estimular a lipólise. Este controle positivo confirma a capacidade do sistema em responder a um estímulo lipolítico.

Os resultados para a lipólise são semelhantes aos resultados para lipogênese e, novamente parecem demonstrar que a adição de PVA ao meio de cultura não altera o metabolismo dos explantes. Isto está demonstrado mesmo para o período mais longo de cultura utilizado (48 horas) e confirma que este composto pode ser adicionado sem alterar as respostas celulares.

Além dos efeitos da albumina sobre a síntese de lipídios in vitro, há inconsistência nas metodologias propostas, na literatura, para formação do complexo 
AG:BSA. A metodologia utilizada por Park et al. (1997) se diferencia da de Mahoney et al. (1977), na temperatura e período nos quais o complexo permanece para ser formado. Matitashvili et al. (2001) testaram a relação 3:1, de AG:BSA em tecido de glândula mamária de vacas lactantes, enquanto Brown et al. (2001) e Evans et al. (2002) testaram as relações 4:1 e 4:1 de AG:BSA em células de estroma vascular de humanos e préadipócitos 3T3-L1, respectivamente. Foram realizados, também, testes preliminares com estas relações de 3:1 e 4:1 de AG:BSA, bem como alterações nos períodos e temperaturas de formação do complexo, em cultura de explantes de tecido adiposo, mas as respostas para o sistema permaneceram alteradas. Estas variações, na metodologia, podem ser responsáveis pelas respostas variáveis e até contraditórias encontradas nos trabalhos in vitro.

A utilização de PVA vem sendo testada em comparação com a BSA, em modelos de cultura de embrião de camundongos (Nowshari \& Bren, 2000) e de bovinos (Bhuiyan et al., 2004; Orsi \& Leese, 2004). Segundo Nowshari \& Bren (2000) produtos biológicos como a BSA, que são rotineiramente usados em soluções de congelamento de embriões, podem expor os embriões a agentes infecciosos, reforçando, a busca pelo PVA ou fontes alternativas.

O PVA é um polímero com peso molecular semelhante ao da albumina, servindo como uma importante alternativa para carrear ácidos graxos em meio de cultura. Este trabalho demonstra que sua utilização gera maior segurança em relação ao uso da albumina. Com o grande aumento do interesse na pesquisa com lipídios bioativos, estes resultados vão permitir o uso desta molécula no teste de diferentes ácidos graxos em cultura.

\subsection{Conclusões}

A utilização do PVA, em culturas de explante de tecido adiposo, não alterou o padrão de resposta lipogênica e lipolítica, tanto para as culturas Controle quanto para as 
estimuladas com hormônio do crescimento. As culturas reproduziram os mesmos padrões de respostas crônicas ao hormônio do crescimento e agudas à insulina, observados em estudos onde este tratamento foi aplicado in vivo e in vitro.

Em contraste, a albumina sérica bovina estimula a lipogênese e diferentes fontes de albumina geram efeitos inconsistentes no metabolismo de culturas de tecido adiposo. Portanto, a substituição da BSA pelo PVA parece ser uma alternativa para a realização de estudos onde se necessite de uma molécula carreadora de lipídios bioativos. 


\section{EFEITO DO ÁCIDO LINOLÉICO CONJUGADO trans-10, cis-12 EM CULTURAS DE EXPLANTE DE TECIDO ADIPOSO DE SUÍNOS EM CRESCIMENTO}

\section{Resumo}

O objetivo deste estudo foi avaliar os efeitos do CLA trans-10, cis-12 em culturas de explantes de tecido adiposo de suínos, em crescimento, sobre a lipogênese (taxa de incorporação de glucose- ${ }^{14} \mathrm{C}$ em $2 \mathrm{~h}$ de incubação na presença e ausência de insulina), lipólise (liberação de ácido graxos não esterificados - AGNE - em $2 \mathrm{~h}$ de incubação na presença e ausência de isoproterenol), atividades de enzimas lipogênicas e abundância do RNA mensageiro (RNAm) do gene da sintase de ácido graxo (FAS). Explantes de tecido adiposo de nove suínos, em crescimento, $(78 \pm 3 \mathrm{~kg})$ foram submetidos à cultura em meio 199 com insulina, dexametasona e antibióticos por 4, 12, 24 e 48 horas. Tratamentos foram: Controle - $100 \mu \mathrm{M}$ de PVA (poliivinil álcool); CLA200: $200 \mu \mathrm{M}$ de CLA trans-10, cis-12; CLA50: $50 \mu \mathrm{M}$ de CLA trans-10, cis-12; LA: $200 \mu \mathrm{M}$ de ácido de linoléico e pGH: $100 \mathrm{ng} / \mathrm{mL}$ de pGH (hormônio do crescimento suíno) e $100 \mu \mathrm{M}$ de PVA. Os ácidos graxos foram complexados ao PVA (2:1), por 24 horas. Depois de cada período de cultura, os explantes foram submetidos ao ensaio de lipogênese. Após 24 h, transcritos de RNAm da FAS foram quantificados por RT-PCR em Tempo Real. A lipólise e atividade das enzimas FAS, glucose 6-fosfato desidrogenase, 6-fosfogluconato desidrogenase e NADP-malato desidrogenase, foram avaliadas após 48 horas. A incorporação de glucose diminuiu $(\mathrm{P}<0,05)$ com o tratamento controle positivo (pGH). O ácido linoléico não teve nenhum efeito nos parâmetros avaliados. O tratamento com CLA trans-10, cis-12 causou diminuição na atividade da 
FAS $(\mathrm{P}<0,05)$, mas as enzimas da síntese de NADPH não foram afetadas por nenhum tratamento. Coerente com a diminuição na atividade da FAS, sob efeito do tratamento crônico com CLA, a síntese lipídica e abundância de RNAm foram reduzidas. O controle positivo pGH aumentou a lipólise basal e estimulada $(\mathrm{P}<0,05)$ após $48 \mathrm{~h}$ de cultura, mas o tratamento com CLA não afetou a liberação de AGNE. Estes dados sugerem que o CLA trans-10, cis-12 altera a lipogênese e, particularmente a FAS, mas não afeta a lipólise em cultura de tecido adiposo de suínos

\section{EFFECTS OF trans-10, cis-12 CONJUGATED LINOLEIC ACID ON CULTURES OF ADIPOSE TISSUE EXPLANTS OF GROWING PIGS}

\section{Summary}

The objective of this study was to evaluate the effects of trans-10, cis-12 CLA on cultures of adipose tissue explants from growing pigs on lipogenesis (measured as rate of ${ }^{14} \mathrm{C}$ labeled glucose incorporation over a subsequent $2 \mathrm{~h}$ incubation in presence or absence of insulin), lipolysis (release of non-esterified fatty acid - NEFA - over a $2 \mathrm{~h}$ incubation in presence or absence of isoproterenol), activities of lipogenics enzymes and mRNA abundance of fatty acid synthase (FAS) gene. Adipose tissue explants from nine growing pigs $(78 \pm 3 \mathrm{~kg})$ were cultured in medium 199 with insulin, dexamethasone and antibiotics for 4, 12, 24 and 48 hours. Treatments were Control: $100 \mu \mathrm{M}$ of PVA (polyvinyl alcohol); CLA200: $200 \mu \mathrm{M}$ of trans-10, cis-12 CLA; CLA50: $50 \mu \mathrm{M}$ of trans-10, cis-12 CLA; LA: $200 \mu \mathrm{M}$ of linoleic acid and pGH: $100 \mathrm{ng} / \mathrm{mL}$ (porcine growth hormone) and $100 \mu \mathrm{M}$ of PVA. The fatty acids were complexed to PVA (2:1), for 24 hours. After each culture period explants were collected and assayed for lipogenesis. After $24 \mathrm{~h}$ transcripts of FAS mRNA were quantified by Real Time RTPCR. Lipolysis and activities of enzymes FAS, glucose 6-phosphate dehydrogenase, 6phosphogluconate dehydrogenase and NADP-malate dehydrogenase were evaluated after 48 hours Glucose incorporation was decreased $(\mathrm{P}<0.05)$ in response to $\mathrm{pGH}$ treatment (positive control). Linoleic acid had no effect on any parameter evaluated. 
Treatment with trans-10, cis-12 CLA decreased FAS activity $(\mathrm{P}<0.05)$, but NADPH generating enzymes were not affected by any of the treatments. Consistent with the reduction on FAS activity, under chronic treatment with CLA, lipid synthesis and FAS mRNA abundance were reduced. The positive control pGH increased basal and stimulated lipolysis $(\mathrm{P}<0.05)$ after $48 \mathrm{~h}$ of culture, but CLA treatment had not effect on NEFA release. These data suggest trans-10, cis-12 CLA alters lipogenesis and particularly FAS, but does not affect lipolysis on cultures of pig adipose tissue.

\subsection{Introdução}

Desde a descoberta de uma substância presente na carne bovina, capaz de reduzir o número de tumores (Pariza et al., 1979), diversos trabalhos demonstraram que este efeito é mediado por, um ácido linoléico conjugado. Este composto é encontrado no leite e carne de ruminantes, sendo formado como um intermediário na via da biohidrogenação do ácido linoléico a ácido esteárico, por microorganismos presentes no rúmen e em menor grau no intestino grosso. Existem mais de 20 diferentes isômeros do ácido linoléico conjugado, na natureza, que são coletivamente chamados de CLAs.

Estudos demonstraram que os efeitos dos diferentes isômeros de CLA são relacionados à antiobesidade, alteração da composição corporal de camundongos (Park et al., 1997) e suínos (Bee, 2000; Dugan et al., 1999; Dugan et al., 1997; Ostrowska et al., 1999; Thiel-Cooper et al., 2001), alterações na gordura do leite de vacas (Baumgard et al., 2000; Chouinard, et al., 1999; Giesy et al., 1999; Medeiros et al., 2000) e sobre a atividade de enzimas lipogênicas (Hayashi, 2003; Piperova et al., 2000; Lin et al., 2004).

Dentre os diversos isômeros de CLA, o trans-10, cis-12 é considerado responsável por reduzir a síntese de gordura na glândula mamária e as concentrações de RNA mensageiro (RNAm) de enzimas lipogênicas neste tecido (Baumgard et al., 2002; Peterson et al.; 2003). Este isômero também está envolvido em mudanças na composição corporal de camundongos, com redução na deposição de gordura e redução na atividade da enzima lipoproteína lipase, em culturas de adipócitos de camundongos 3T3-L1 (Park et al., 1999). Efeitos do trans-10, cis-12 incluem inibição da atividade da 
estearoil coenzima A dessaturase (SCD) (Baungard et al. 2001; Park et al., 2000) e redução da abundância do seu RNAm (Choi et al., 2000; Lee et al., 1998), efeitos antiadipogênicos em humanos (Brown \& McIntosh, 2003) e aumento na razão LDL:HDL em humanos saudáveis (Tricon et al., 2004).

Entretanto, a maioria das observações dos efeitos dos diferentes CLAs e do isômero trans-10, cis-12, foi conduzida em modelos animais distintos, usando mistura com diversos isômeros, doses distintas, com administrações in vivo e avaliações in vitro, ou mesmo com administração in vitro, mas com linhagens celulares (e.g. 3T3-L1). Não é de se estranhar, portanto, que os resultados encontrados sejam bastante variáveis.

Uma ferramenta, para avaliação dos mecanismos de ação do CLA, é cultura de explantes de tecidos, por permitir a condução simultânea de muitas avaliações. No caso de culturas primárias, há vantagens em termos de semelhança das respostas em relação às linhagens celulares que já sofreram diversas mutações.

Em suínos, em crescimento, o tecido adiposo é muito importante fisiológica e economicamente. Este tecido armazena as reservas energéticas corporais, predominantemente na forma de lipídios (Bauman \& Davis, 1975). Em função das dietas utilizadas para esta espécie, a síntese de lipídios ocorre principalmente pela via de novo, utilizando glucose como substrato. Geralmente as mudanças nas taxas de síntese lipídica são paralelas às mudanças nas atividades de enzimas (Sinnet-Smith et al.1979), como a sintase de ácido graxo (FAS), considerada entre as mais importantes reguladoras desta via bioquímica.

Assim, o objetivo deste trabalho foi observar o efeito do tratamento com um isômero específico, trans-10, cis-12, do CLA no metabolismo lipídico de suínos em crescimento, especificamente, em culturas de explante de tecido adiposo subcutâneo. Portanto, esse efeito foi avaliado para taxa de síntese de lipídios, mobilização de lipídios, abundância de RNAm para o gene da FAS e atividade enzimática da FAS, glucose 6fosfato desidrogenase (G6PDH), 6-fosfogluconato desidrogenase (6PGDH) e NADPmalato desidrogenase (NADP-MD). 


\subsection{Material e Métodos}

\subsubsection{Culturas de explantes de tecido adiposo de suínos}

Nove suínos Landrace $\mathrm{x}$ Large White do Departamento de Zootecnia ESALQ/USP, com peso médio de $78+$ ou $3 \mathrm{~kg}$, foram abatidos e, aproximadamente, 20 $\mathrm{g}$ de tecido adiposo subcutâneo coletados da região dorsal posterior do pernil. Imediatamente, foram transportados em tampão (25 mM de HEPES; 0,15 M de NaCl; 20 $\mathrm{U} / \mathrm{mL}$ de penicilina; $20 \mu \mathrm{g} / \mathrm{mL}$ de estreptomicina; $5 \mu \mathrm{g} / \mathrm{mL}$ de neomicina e $2,5 \mu \mathrm{g} / \mathrm{mL}$ de anfotericina B - Sigma; $\left.37^{\circ} \mathrm{C}, \mathrm{pH} 7,4\right)$. Explantes de 50-100 $\mathrm{mg}$ foram preparados a partir da camada intermediária do tecido subcutâneo, em condições assépticas, e incubados em meio 199 (25 mM de HEPES; $25 \mathrm{mM}$ de bicarbonato; $20 \mathrm{U} / \mathrm{mL}$ de penicilina; $20 \mu \mathrm{g} / \mathrm{mL}$ de estreptomicina; $5 \mu \mathrm{g} / \mathrm{mL}$ de neomicina e $2,5 \mu \mathrm{g} / \mathrm{mL}$ de anfotericina B - Sigma; $\left.37^{\circ} \mathrm{C}, \mathrm{pH} 7,4\right)$ de acordo com metodologia descrita por Lanna et al. (1995). Ao meio de cultura foram adicionados os tratamentos: a) Controle - 100 $\mathrm{ng} / \mathrm{mL}$ de insulina, $10 \mathrm{nM}$ de dexametasona e $100 \mu \mathrm{M}$ de poliivinil álcool (PVASigma); b) pGH - $100 \mathrm{ng} / \mathrm{mL}$ de insulina, $10 \mathrm{nM}$ de dexametasona, $100 \mathrm{ng} / \mathrm{mL}$ de $\mathrm{pGH}$ (hormônio do crescimento recombinante suíno - Reporcin ${ }^{\circledR}$, Southern Cross Biotech) e $100 \mu \mathrm{M}$ de PVA; c) CLA200 - $100 \mathrm{ng} / \mathrm{mL}$ de insulina, $10 \mathrm{nM}$ de dexametasona e 200 $\mu \mathrm{M}$ de ácido linoléico conjugado trans-10, cis-12; d) CLA50 - $100 \mathrm{ng} / \mathrm{mL}$ de insulina, $10 \mathrm{nM}$ de dexametasona e $50 \mu \mathrm{M}$ de ácido linoléico conjugado trans-10, cis-12; e) LA $100 \mathrm{ng} / \mathrm{mL}$ de insulina, $10 \mathrm{nM}$ de dexametasona e $200 \mu \mathrm{M}$ de ácido linoléico (LA Sigma). As placas foram mantidas em atmosfera contendo $95 \%$ Ar: $5 \% \mathrm{CO}_{2}$ a $37^{\circ} \mathrm{C}$ por 4, 12, 24 e 48 horas.

Após esses períodos de cultura, os explantes foram submetidos às incubações para determinação da lipogênese ou lipólise. Outros explantes foram coletados após 24 ou 48 horas de cultura e, imediatamente, congelados em $\mathrm{N}_{2}$ líquido, para posterior quantificação da abundância do RNAm para o gene da FAS ou análises enzimáticas. 


\subsubsection{Formação do complexo ácido graxo - poliivinil álcool}

Para apresentação do substrato à cultura, o ácido graxo testado foi complexado com PVA. Foram diluídos o CLA ou LA em dimetilsulfoxido (DMSO - Sigma) e adicionado em 2,5 mM de PVA em PBS (tampão salino fosfato, pH 7,4), em condições assépticas, e o pH ajustado para 7,4 a $37^{\circ} \mathrm{C}$, mantidos por 24 horas. O tratamento controle, com PVA apenas, foi preparado da mesma forma, excetuando-se a adição de ácido graxo. A relação ácido graxo - poliivinil álcool foi de 2:1 e as doses de CLA, utilizadas nas culturas de explantes de tecido adiposo, foram obtidas em ensaios preliminares. No tratamento CLA200, a concentração do suplemento contendo CLA foi de $212 \mu \mathrm{M}$, para que a concentração final fosse de $200 \mu \mathrm{M}$ do isômero trans-10, cis-12. Este CLA foi gentilmente cedido por Baungard et al. (2000) e sua composição pode ser observada na Tabela 3.

Tabela 3. Análise de perfil de ácidos graxos do ácido linoléico conjugado utilizado

\begin{tabular}{cc}
\hline Ácidos graxos & $\mathrm{g} / 100 \mathrm{~g}$ \\
\hline $16: 0$ & 1 \\
$18: 0$ & 0,3 \\
$18: 1$ cis- 9 & 0,4 \\
$18: 2$ cis-9, cis-12 & 0,4 \\
$18: 2$ cis- 9, trans-11 & 2,2 \\
$18: 2$ trans-10, cis-12 & 94,5 \\
não determinado & 1,2 \\
\hline
\end{tabular}

Fonte: Natural Lipids Hovdebygda, Norway Ltd.

\subsubsection{Ensaio de Lipogênese}

Após cada período de incubação, os explantes foram coletados e transferidos para frascos de cintilação contendo $2 \mathrm{~mL}$ de meio de lipogênese (KRB 1X - Krebs Ringer buffer - 0,65 mM de $\mathrm{CaCl}_{2} ; 10 \mathrm{mM}$ de HEPES; $10 \mathrm{mM}$ de glucose e 0,5 $\mu \mathrm{Ci} / \mathrm{mL}$ de glucose D- $\left[{ }^{14} \mathrm{C}(\mathrm{U})\right]$ - Amersham Biosciences; pH 7,4 a $37^{\circ} \mathrm{C}$ ), sob atmosfera de $95 \%$ 
$\mathrm{O}_{2}: 5 \% \mathrm{CO}_{2}$, sob agitação, por 2 horas, a $37^{\circ} \mathrm{C}$. Foram realizadas triplicatas das incubações: a) Lipogênese Basal - sem adições; b) Lipogênese INS - estimulada com $1000 \mathrm{ng} / \mathrm{mL}$ de insulina. Posteriormente, foram submetidos às extrações de lipídios, segundo Folch et al. (1957), com algumas modificações. Os explantes foram transferidos para frascos de extração contendo $5 \mathrm{~mL}$ de metanol:clorofórmio 1:2. Após permanecerem em descanso por 1 hora, adicionou-se $1 \mathrm{~mL}$ de $\mathrm{NaCl} 1 \%$ e a extração prosseguiu por 12 a 16 horas. À fase inferior, foram adicionados $0,5 \mathrm{~mL}$ de hexano e 5 $\mathrm{mL}$ de líquido de cintilação (Sigma). Os frascos de cintilação foram encaminhados para o Laboratório de Experimentação Nuclear, CENA/USP, para leitura em cintilador automático (Beckman Instruments- LS 5000 TD - Liquid Scintillation System) e a lipogênese expressa em nanomoles de glucose incorporada por grama de tecido por 2 horas.

\subsubsection{Quantificação do RNA mensageiro da sintase de ácido graxo}

\subsubsection{Extração de RNA total e síntese de DNAc}

O RNA total foi isolado dos explantes, utilizando-se o reagente Trizol (Invitrogen). Amostras foram dissolvidas em água livre de RNAases e quantificadas em espectofotômetro a $260 \mathrm{~nm}$ (A260). A pureza do RNA total foi determinada pela relação A260:A280 e a integridade, observada em eletroforese em gel de agarose 1\%. Amostras de DNAc (DNA complementar a população de RNAm) foram preparadas a partir de 3 $\mu \mathrm{g}$ de RNA total, usando como primer oligo (dT). A síntese de DNAcs foi feita com o emprego do Kit SuperScript First-Strand Synthesis System for RT-PCR (Invitrogen), segundo protocolo do fabricante.

\subsubsection{PCR em Tempo Real}

A RT-PCR em Tempo Real é uma técnica rápida e acurada que permite a quantificação dos produtos da PCR, em tempo real, sendo sensível para quantificar os produtos na fase exponencial da reação. 
O método escolhido para a quantificação dos resultados foi o método de quantificação relativa, uma vez que não é necessário saber o número absoluto de transcritos de cada gene e sim a diferença de expressão em relação a um gene constitutivo. Para tanto, utilizou-se, como gene controle, a $\beta$-actina (Giulietti et al. 2001) e os resultados foram analisados segundo Pfaffl (2001).

As reações de PCR continham $2 \mu \mathrm{L}$ de DNAc, $0,25 \mu \mathrm{M}$ dos primers direto e reverso, para cada gene, e $1 \mathrm{X}$ Absolute ${ }^{\mathrm{TM}}$ QPCR SYBR ${ }^{\circledR}$ Green Mix - ABgene, em um volume final de $10 \mu \mathrm{L}$ (50 ciclos de reação, denaturação a $95^{\circ} \mathrm{C}$ por $10 \mathrm{seg}$., anelamento a $56^{\circ} \mathrm{C}, 15 \mathrm{seg}$. e extensão a $72^{\circ} \mathrm{C}, 20$ segundos). Os primers foram desenhados para amplificação de um produto de 126 pares de bases (pb) de DNAc do gene da FAS (5' CGG CTC ACA CAC CTT CGT 3'- direto e 5' TGC TCC ATG TCG GTG AAC T 3'reverso) e um fragmento de $150 \mathrm{pb}$ para o gene da $\beta$-actina (5' TGG TGG GTA TGG GTC AGA A 3' - direto e 5' GCT CGT TGT AGA AGG TGT GG 3'- reverso, Dialab Diagnóstico). As quantificações foram realizadas no Laboratório de Melhoramento de Plantas, CENA/USP, no equipamento RotorGene 3000 (Corbett Research).

\subsubsection{Ensaio de lipólise}

Após os períodos de incubação de 48 horas, os explantes foram coletados e incubados em $2 \mathrm{~mL}$ de meio de lipólise (KRB $1 \mathrm{X}-0,65 \mathrm{mM}$ de $\mathrm{CaCl}_{2} ; 2,5 \mathrm{mM}$ de

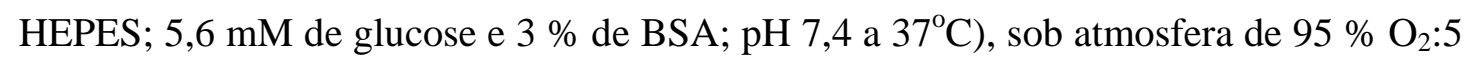
$\% \mathrm{CO}_{2}$, sob agitação, por 2 horas, a $37^{\circ} \mathrm{C}$. Foram realizadas triplicatas das incubações: a) Lipólise Basal - sem adições e b) Lipólise ISO - estimulada com $10^{-5} \mathrm{M}$ de isoproterenol. Após este período, alíquotas dos meios foram coletadas para análise de ácidos graxos não esterificados (AGNE). A concentração de AGNE foi determinada por método enzimático colorimétrico, a $540 \mathrm{~nm}$, utilizando-se o kit NEFA $\mathrm{C}^{\circledR}$ (Wako Chemicals). As leituras de absorbância foram realizadas no Laboratório Biologia Molecular de Plantas, ESALQ/USP, em Leitor de Elisa (Spectra Max Plus - Molecular Devices), utilizando-se microplacas com poços de $200 \mu \mathrm{L}$ onde foram adicionadas amostras, padrões e reagentes. Os valores de absorbâncias foram convertidos em concentração ( $\mu$ mol de ácido oléico/L) através da curva-padrão determinada e as 
concentrações de AGNE obtidas foram corrigidas para o peso, em gramas, de cada explante e expressas em $\mu$ moles de ácido oléico por g de tecido por 2 horas.

\subsubsection{Ensaios enzimáticos}

\subsubsection{Homogeneização dos explantes de tecido adiposo}

As amostras da cultura de tecido adiposo subcutâneo foram, ainda congeladas, adicionadas em tampão contendo $0,15 \mathrm{M} \mathrm{KCl}, 50 \mathrm{mM}$ Tris, $1 \mathrm{mM}$ Glutationa e $1 \mathrm{mM}$ EDTA ( $\mathrm{pH} \mathrm{7,4} \mathrm{a} 4^{\circ} \mathrm{C}$ ) e homogeneizadas rapidamente em homogeneizador (Polytron PT MR 21-00, Kinematica $A G)$, seguindo-se centrifugação a $4^{\circ} \mathrm{C}, 2000$ x g por $15 \mathrm{~min}$., centrifugado, novamente, por $30 \mathrm{~min} ., 4^{\circ} \mathrm{C}$ e $27000 \mathrm{x}$ g. Parte do homogenato obtida foi utilizada para determinação do teor de proteína e parte, nos ensaios enzimáticos.

\subsubsection{Teor de proteína}

O teor de proteína dos homogenatos foi determinado com reagente Biureto segundo Gornall et al. (1949).

\subsubsection{Sintase de ácido graxo (EC 2.3.1.85)}

O ensaio da enzima FAS foi realizado de acordo com Ingle et al. (1973), com algumas modificações. As concentrações dos reagentes foram: $40 \mathrm{mM}$ de tampão fosfato-potássio mais EDTA ( $\mathrm{pH}$ 6,8), 0,1 mM malonil CoA, 0,1 mM acetil CoA, 0,3 mM NADPH e 0,4 mM ditiotreitol. A atividade foi determinada através do acompanhamento da transformação de NADPH em NADP em incubações contendo substratos, cofatores e o homogenato do tecido adiposo em cubetas sob espectofotômetro a $340 \mathrm{~nm}$ e, expressa, em nmoles de NADPH incorporado/min. $\mathrm{mg}$ de proteína. 


\subsubsection{NADP-malato desidrogenase (EC 1.1.1.40)}

O ensaio da enzima NADP-malato desidrogenase foi realizado segundo Bauman et al. (1970). A atividade foi determinada monitorando-se a transformação de NADP em NADPH em incubações, contendo substratos, cofatores e o homogenato em cubetas sob espectofotômetro a $340 \mathrm{~nm}$ e, expressa, em nmoles de NADPH produzido/min. mg de proteína.

\subsubsection{Atividade da 6-fosfogluconato desidrogenase (EC 1.1.1.44) e glucose 6-fosfato desidrogenase (EC 1.1.1.49)}

Os ensaios foram realizados segundo Glock \& McLean (1953). A atividade da 6fosfogluconato desidrogenase foi determinada através do monitorar da transformação de NADP em NADPH, em incubações contendo substratos, cofatores e o homogenato em cubetas sob espectofotômetro a $340 \mathrm{~nm}$ e, expressa, em nmoles de NADPH produzido/min. mg de proteína. Para determinação da atividade da glucose 6-fosfato desidrogenase, foram medidas as atividades de ambas as enzimas, conjuntamente, e, a partir da atividade obtida, subtraída a atividade da 6 fosfogluconato desidrogenase.

\subsubsection{Análise estatística}

Análises estatísticas foram realizadas utilizando-se o Proc Mixed (SAS, 1999). Para análise de variância do ensaio de lipogênese, com medidas repetidas no tempo, foi utilizado um modelo envolvendo os efeitos fixos de tratamentos, estímulo, tempo e suas interações e efeitos aleatórios de animal dentro do tratamento e animal dentro do tratamento*estímulo que foram os erros para testar efeito de tratamento e de estímulo, respectivamente. Tendo em vista que o tempo não foi igualmente espaçado, foi usada a estrutura de covariância do tipo SP(POW) (tempo), conforme recomendado (Littel et al., 1996).

No ensaio de lipólise, a análise de variância foi feita de acordo com o modelo de experimento com parcela subdividida, tendo tratamentos aplicados nas parcelas e 
estímulo às subparcelas. Para os dados de atividade das enzimas e RNAm, a análise de variância foi baseada no modelo inteiramente casualizado. Comparações de médias foram feitas pelo teste de Tukey.

\subsection{Resultados e Discussão}

Na Tabela 4 observam-se os resultados obtidos do efeito dos tratamentos nas culturas de explantes de tecido adiposo incubadas, por 4, 12, 24 e 48 horas, sobre a incorporação de glucose marcada com ${ }^{14} \mathrm{C}$. Foram detectados efeitos para tratamento $(\mathrm{P}=0,008)$ e tempo $(\mathrm{P}<0,001)$. Não foi detectado efeito para as interações: tratamento*estímulo $(\mathrm{P}=0,41)$, tratamento*tempo $(\mathrm{P}=0,69)$, tempo*estímulo $(\mathrm{P}=0,41)$ e tempo*tratamento*estímulo $(\mathrm{P}=0,99)$ e para Basal: 5019,80 e Insulina: 5764,14 em nanomoles de glucose incorporada/g.2h $(\mathrm{P}=0,05)$.

Tabela 4. Taxas de lipogênese em explantes de tecido adiposo, após 4, 12, 24 e 48 horas de cultura com diferentes tratamentos

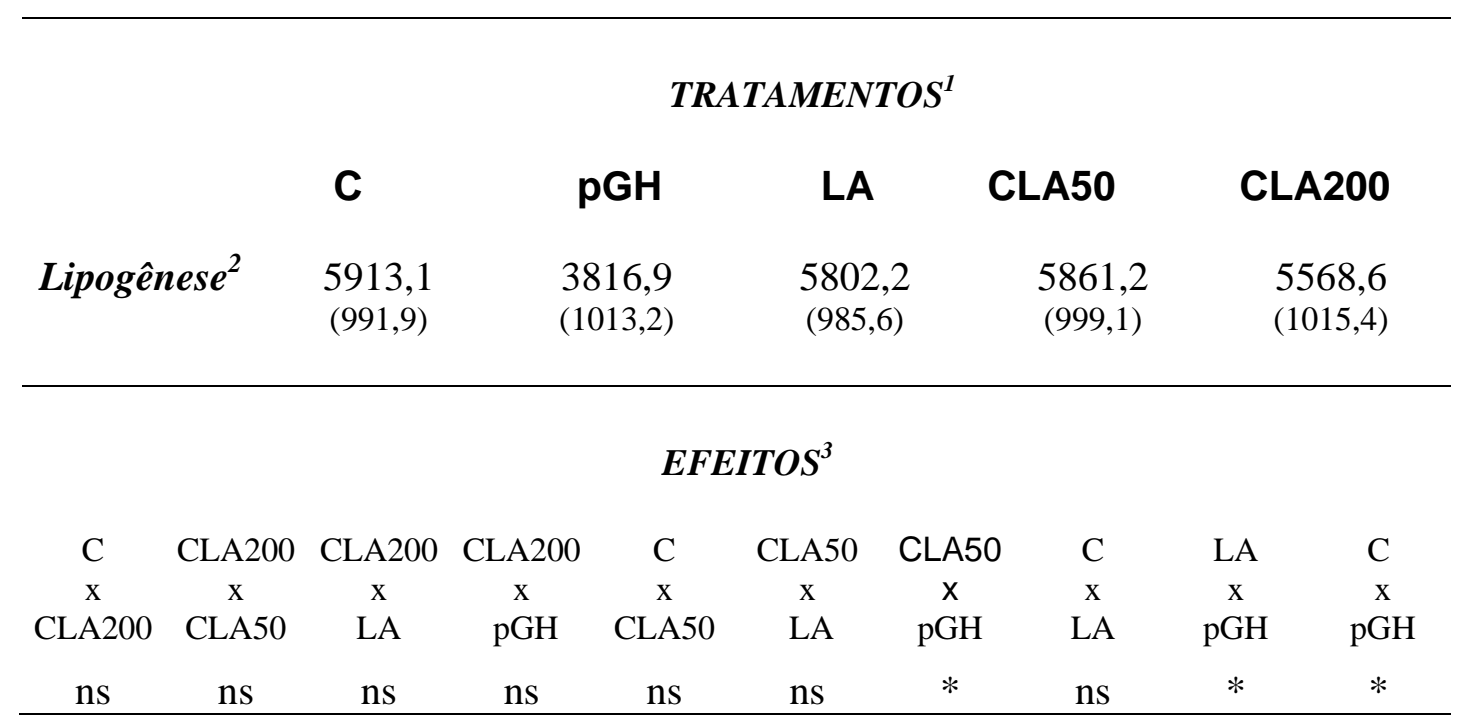

${ }^{1}$ Tratamentos: C: controle (100 $\mu \mathrm{M}$ de PVA); pGH: $100 \mathrm{ng} / \mathrm{mL}$ de pGH; LA: $200 \mu \mathrm{M}$ de LA; CLA50: $50 \mu \mathrm{M}$ de CLA trans-10, cis-12 e CLA200: $200 \mu \mathrm{M}$ de CLA trans-10, cis-12.

${ }^{2}$ Lipogênese: médias e seus respectivos erros-padrão, das culturas de explante de tecido adiposo de 9 animais.

${ }^{4}$ Probabilidade das diferenças entre tratamentos $(* \mathrm{P}<0,05$; ns: $\mathrm{P}>0,10)$. 
Foi observada uma queda na taxa de incorporação de ${ }^{14} \mathrm{C}$ ao longo dos períodos de incubação. Embora esta queda tenha sido um pouco superior à observada em outros trabalhos, as taxas finais são altas o suficiente para demonstrar que os explantes de tecido adiposo estavam metabolicamente ativos. $\mathrm{O}$ fato de que as culturas responderam ao efeito do pGH, nas últimas 24 horas, demonstra também que o tecido estava respondendo ao controle positivo. Entretanto, o efeito de inibição da síntese de gordura pelo pGH foi menor do que o observado em experimentos sob as mesmas condições de cultura de tecido adiposo de suínos (Etherton et al., 1995; Lanna et al., 1994) e de vacas em lactação in vivo e in vitro (Lanna \& Bauman, 1999; Lanna et al., 1995). Este fato pode ter ocorrido devido ao alto coeficiente de variação observado nas triplicatas de incubação.

Uma hipótese deste trabalho era de que o CLA reduziria a taxa lipogênica. Entretanto este efeito não foi demonstrado, apesar de haver uma diferença numérica neste sentido. Alterações na lipogênese podem ser função de diferenças na quantidade de enzimas chave na via bioquímica, na ativação destas enzimas e na quantidade de substratos presentes. No caso da lipogênese, além da FAS, também, a atividade da enzima acetil coenzima A carboxilase (ACC) é muito importante. Com relação à quantidade de substrato, um possível efeito do CLA no transportador de glucose 4 (Glut 4) poderia afetar a entrada de substratos na célula. A redução no RNAm do Glut 4, no tecido adiposo marrom e branco de camundongos tratados com uma mistura de isômeros de CLA, foi observada após 21 dias de administração (Takahashi et al., 2002).

Os efeitos do CLA, bem como os mecanismos envolvidos na incorporação lipogênica, ainda não são totalmente esclarecidos. Satory \& Smith (1999) observaram que uma mistura de isômeros de CLA (41\% cis-9, trans-11 e 44 \% trans-10, cis-12) na dosagem de $6 \mu \mathrm{M}$ promoveu o acúmulo de lipídios através da via de novo (i.e. que utiliza a glucose como substrato) em pré-adipócitos 3T3-L1. De forma contraditória, Park et al. (1997) observaram redução na atividade da lipoproteína lipase com um aumento na liberação de AGNE, no meio de cultura, utilizando a mesma linhagem celular, mas com uma dose maior $(100 \mu \mathrm{M})$ de outra mistura de isômeros de CLA (aproximadamente $50 \%$ cis-9, trans-11 e $50 \%$ trans-10, cis-12). Certamente que as 
diferentes misturas de isômeros e as diferentes doses empregadas podem explicar estes efeitos contrastantes. Entretanto, a maior parte dos trabalhos é consistente em demonstrar um efeito do isômero trans-10, cis-12 na lipogênese. Estes efeitos parecem estar ligados à interação entre os CLAs e alguns fatores de transcrição, entre eles, proteína de ligação ao elemento regulatório de esterol (SREBP; Takahashi et al., 2003).

De acordo com a hipótese deste trabalho, e também com a menor taxa numérica de síntese de lipídios na presença de CLA, a atividade da FAS (Tabela 5) foi reduzida pelo tratamento com CLA trans-10, cis-12 na dose mais elevada $(200 \mu \mathrm{M})$. Além do efeito observado para o tratamento CLA200, houve um efeito para o pGH, mais uma vez acompanhando a diminuição da taxa de lipogênese. Em função da meia vida da proteína ser superior a 48 h (Dice \& Goldberg, 1975), mesmo no caso das incubações de longo prazo (i.e. 48 horas), é possível que o período relativamente curto dificulte que se demonstrem efeitos na concentração desta enzima. Entretanto, os efeitos do CLA foram pronunciados e, mesmo no tratamento com o $\mathrm{pGH}$, superiores aos observados em outros trabalhos (Lanna et al., 1994).

Tabela 5. Atividades enzimáticas de explante de tecido adiposo, após 48 h de cultura

\section{TRATAMENTOS ${ }^{1}$}

\begin{tabular}{cccccc} 
ENZIMAS $^{2}$ & C & pGH & LA & CLA50 & CLA200 \\
\hline FAS & $22(5,10)^{\mathrm{a}}$ & $6,7(5,60)^{\mathrm{b}}$ & $22,2(4,30)^{\mathrm{a}}$ & $17,1(4,70)^{\mathrm{ab}}$ & $8,6(4,70)^{\mathrm{b}}$ \\
G-6PDH & $46,1(9,60)^{\mathrm{a}}$ & $43,9(14,0)^{\mathrm{a}}$ & $64(9,30)^{\mathrm{a}}$ & $58,1(10,7)^{\mathrm{a}}$ & $64,6(10,6)^{\mathrm{a}}$ \\
& & & & \\
6-PGDH & $41,3(4,60)^{\mathrm{a}}$ & $44,5(5,70)^{\mathrm{a}}$ & $39,7(3,90)^{\mathrm{a}}$ & $45,2(5,70)^{\mathrm{a}}$ & $54,5(5,00)^{\mathrm{a}}$ \\
& & & & \\
NADP-MD & $131,8(10,8)^{\mathrm{a}}$ & $136,1(11,8)^{\mathrm{a}}$ & $139,3(10,1)^{\mathrm{a}}$ & $123,1(10,1)^{\mathrm{a}}$ & $144(10,1)^{\mathrm{a}}$ \\
\hline
\end{tabular}


As reduções nas atividades da FAS não foram acompanhadas por reduções semelhantes nas atividades das enzimas do ciclo das pentoses (i.e. produção de NADPH) (Tabela 5). Isto é esperado uma vez que diversos tratamentos de efeito pronunciado sobre a síntese de lipídios, inclusive o hormônio do crescimento, não têm demonstrado efeitos paralelos nas atividades das enzimas que geram NADPH (Hayashi, 2003; Lanna, 1993). Isto sugere que a abundância destas enzimas é tal que elas não funcionam como reguladoras destas vias bioquímicas.

Coerente com a menor atividade encontrada para a FAS, e também com a menor a taxa numérica de lipogênese, a abundância de RNAm para a FAS, após 24 horas de cultura foi reduzida em relação ao controle (Tabela 6). Este efeito do CLA trans-10, cis12 era esperado em função da literatura ter demonstrado tais reduções, principalmente, em tecido da glândula mamária (Matitashvili et al., 2001).

A razão da transcrição do RNAm da FAS corrigida para a transcrição da $\beta$-actina e as eficiências de amplificação, foi de 74 e $76 \%$ em relação ao controle (Tabela 6). Estes valores são pequenos, mas semelhantes às diferenças observadas para as taxas lipogênicas. São valores bastante distintos das mudanças na atividade da FAS, embora a razão para esta discrepância não esteja clara. Não houve diferença na abundância relativa do RNAm da FAS para o tratamento com CLA, na dose mais baixa $(50 \mu \mathrm{M})$. Entretanto, para o tratamento com LA a quantidade de RNAm foi maior do que para o tratamento controle e para ambos os tratamentos com CLA. 
Tabela 6. Valores de transcritos do RNA mensageiro da FAS

\section{TRATAMENTOS ${ }^{1}$}

\begin{tabular}{cccccc} 
& C & pGH & LA & CLA50 & CLA200 \\
\hline RNAm $^{2}$ & - & 0,74 & 1,45 & 1 & 0,76
\end{tabular}

${ }^{1}$ Tratamentos: C: controle; LA: $200 \mu \mathrm{M}$ de LA; pGH: $100 \mathrm{ng} / \mathrm{mL}$ de pGH; CLA200: $200 \mu \mathrm{M}$ de CLA trans-10, cis-12 e CLA50: $50 \mu \mathrm{M}$ de CLA trans-10, cis-12.

${ }^{2}$ Valores dos transcritos do RNAm para o gene da FAS em relação à transcrição da $\beta$-actina, para cada tratamento, em relação ao tratamento controle.

Em experimentos onde foram observadas alterações na abundância de RNAm das enzimas envolvidas no metabolismo lipídico, as dietas com CLA trans-10, cis-12 foram administradas por um período de tempo maior (3 semanas). Após 3 semanas Peterson et al. (2003) observaram reduções na abundância do RNAm da FAS e ACC, em biópsias de tecido da glândula mamária de vacas lactantes, condizentes com alterações na secreção dos ácidos graxos na gordura do leite. Entretanto, Choi et al. (2000) com linhagens de pré-adipócitos 3T3-L1, mantidas com CLA trans-10, cis-12, durante a diferenciação, não observaram alterações na expressão da FAS, medida pelo seu RNAm.

Em trabalho anterior, testando o efeito do pGH sob as mesmas condições de cultura, José (2000) observou uma redução de $22 \%$ na atividade enzimática da FAS, acompanhada de uma redução na abundância do RNAm de 70\%, após 48 horas de incubação. Neste trabalho os efeitos foram semelhantes em direção, mas de magnitudes diferentes. A diferença entre a meia vida da proteína da FAS (i.e. em torno de 48 horas) e do RNAm correspondente (i.e. 3 a 5 horas; Back et al., 1986) sugerem que se esperaria uma diferença maior para a abundância de RNAm em relação à proteína.

Baumgard et al. (2002) observaram uma redução na abundância do RNAm da FAS, ACC e SCD, em biópsias de glândula mamária de vacas que receberam infusão abomasal de CLA trans-10, cis-12. Entretanto, o período de tratamento foi de 5 dias. Lin et al. (2004), também, observaram uma redução na atividade da ACC e do seu RNAm, na glândula mamária de ratas lactantes que receberam CLA trans-10, cis-12 de 4 a 15 
dias pós-parto. Entretanto, para a FAS, só foi observada redução na abundância do RNAm e não na atividade, apesar do longo período de tratamento. De forma distinta do observado na glândula mamária, no fígado destes mesmos animais, as taxas de atividade e o RNAm da ACC e da FAS não foram afetadas (Lin et al., 2004). Consistente com os dados deste trabalho Hayashi (2003) observou uma redução na atividade da FAS e da G6PDH e 6-PGDH, no fígado e na glândula mamária de ratas que receberam dietas com CLA60 (contendo 35\% de CLA trans-10, cis-12) de 1 aos 15 dias pós-parto. No tecido adiposo das ratas utilizadas por Hayashi (2003) somente a atividade da FAS foi reduzida, semelhantemente aos dados deste trabalho e corroborando dados de redução na atividade da FAS, na glândula mamária de vacas (Piperova et al., 2000). No estudo de Hayashi (2003), como no presente trabalho, não houve diferenças nas atividades das enzimas geradoras de NADPH.

Segundo Mersmann (2001), as respostas com CLA podem diferir entre espécies devido ao padrão do metabolismo lipídico ser espécie-específico, tornando, assim, a comparação dos resultados um pouco delicada. Um aspecto importante nestas comparações é que, nos roedores, o tecido adiposo não é o sítio mais importante quantitativamente na síntese de lipídios, ao contrário dos suínos em que a síntese de novo de gorduras ocorre na grande maioria no próprio tecido adiposo, pela ação de enzimas ali presentes.

Corino et al. (2003) não observaram diminuição na atividade da NADP-MD e G6PDH, no tecido adiposo de suínos que receberam uma mistura de isômeros de CLA. Entretanto, houve uma queda na atividade da ACC. Contraditoriamente, Bee (2000) avaliando o efeito de uma mistura de isômeros de CLA, na dieta inicial dos leitões, observou um aumento da atividade da G-6PDH e NADP-MD no tecido adiposo. Estas mudanças não foram acompanhadas de aumentos na atividade da FAS.

Os efeitos dos tratamentos sobre a lipólise, após 48 h de tratamento em cultura, foram avaliados pela liberação de ácidos graxos não esterificados em período de $2 \mathrm{~h}$ de incubação (Tabela 7) sem adições (basal) e na presença de isoproterenol ( $\beta$ adrenérgico). Houve efeito dos tratamentos $(\mathrm{P}<0,001)$, do estímulo com isoproterenol $(\mathrm{P}<0,001)$, mas não houve efeito para a interação tratamento*estímulo $(\mathrm{P}=0,13)$. 
Tabela 7. Taxas de lipólise em explantes de tecido adiposo mantidos em cultura por 48 horas sob diferentes tratamentos

\begin{tabular}{|c|c|c|c|c|c|c|c|c|c|}
\hline \multicolumn{10}{|c|}{ TRATAMENTOS $^{1}$} \\
\hline & & \multirow[t]{2}{*}{ C } & \multicolumn{2}{|c|}{ pGH } & LA & CLA50 & \multicolumn{2}{|c|}{ CLA200 } & $\mathbf{M}^{2}$ \\
\hline \multicolumn{9}{|c|}{ rmoles de AGNE/g.2 h } & \\
\hline \multicolumn{10}{|c|}{ Estímulo $^{3}$} \\
\hline BASAL & & $1,85(0,73$ & 3,65 & $(0,69)$ & $1,34(0,69)$ & $1,30(0,69$ & & $1,92(0,69)$ & 2,01 \\
\hline ISO & & $4,85(1,4$ & 9,00 & $(0,73)$ & $3,34(0,69)$ & $4,24(0,69$ & & $5,54(0,69)$ & 5,39 \\
\hline \multicolumn{10}{|c|}{ EFEITOS $^{4}$} \\
\hline $\mathrm{C}$ & CLA200 & CLA200 & CLA200 & $\mathrm{C}$ & CLA50 & CLA50 & $\mathrm{C}$ & LA & $\mathrm{C}$ \\
\hline $\mathrm{x}$ & $\mathrm{x}$ & $\mathrm{x}$ & $\mathrm{x}$ & $\mathrm{x}$ & $\mathrm{x}$ & $\mathrm{x}$ & $\mathrm{x}$ & $\mathrm{x}$ & $\mathrm{x}$ \\
\hline CLA200 & CLA50 & LA & pGH & CLA50 & LA & pGH & LA & pGH & pGH \\
\hline ns & ns & ns & $*$ & ns & ns & $* *$ & ns & $* *$ & $*$ \\
\hline
\end{tabular}

${ }^{1}$ Tratamentos: C: controle (100 $\mu \mathrm{M}$ de PVA); pGH: $100 \mathrm{ng} / \mathrm{mL}$ de pGH; LA: $200 \mu \mathrm{M}$ de LA; CLA200: $200 \mu \mathrm{M}$ de CLA trans-10, cis-12 e CLA50: $50 \mu \mathrm{M}$ de CLA trans-10, cis-12.

${ }^{2}$ Valores médios em $\mu$ moles de AGNE por g de tecido por 2 horas, de cada estímulo.

${ }^{3}$ Valores das médias e dos erros-padrão do Basal (sem adições) e ISO $\left(10^{-5} \mathrm{M}\right.$ de isoproterenol), para cada tratamento.

${ }^{4}$ Probabilidade das diferenças entre tratamentos $(* \mathrm{P}<0,05 ; * * \mathrm{P}<0,01$; ns: $\mathrm{P}>0,10)$.

O tratamento com pGH induziu a um aumento da mobilização de AGNE com e sem isoproterenol, o que é consistente com seu efeito em estimular a lipólise. Estes resultados sugerem que os mecanismos lipolíticos dos explantes, em cultura, eram capazes de responder aos tratamentos. Para o tratamento CLA200, tanto na lipólise basal quanto na estimulada, não se observaram diferenças na taxa de liberação de AGNE no meio.

Em pré-adipócitos 3T3-L1 tratados com CLA trans-10, cis-12 por 6 dias observou-se um aumento de $18 \%$ na lipólise basal, medida pela liberação de glicerol em relação ao controle. Houve também um acréscimo de 300 vezes na liberação de glicerol, 
na lipólise estimulada com isoproterenol e adenosina deaminase. Ao contrário, nesta mesma condição de estímulo, o CLA cis-9, trans-11 causou uma queda de $11 \%$ na liberação de glicerol no meio (Evans et al., 2002). Em contraste com estes resultados e semelhantes aos dados obtidos neste estudo, em culturas primárias de células do estroma vascular de tecido adiposo humano, tratadas com trans-10, cis-12 ou cis-9, trans-11, por 3 dias, nenhum isômero de CLA afetou a lipólise medida pela liberação de glicerol (Brown et al., 2001).

A falta de efeito do CLA sobre a lipólise, conforme se observou neste trabalho, por Brown et al. (2001), em tecido adiposo de camundongos (Xu et al., 2003) e em trabalhos in vivo com vacas em lactação (Perfield et al., 2002), sugere que este isômero tem um efeito mais pronunciado na inibição da síntese do que no estímulo à mobilização de gorduras já depositadas. Isto é consistente com o pequeno sucesso deste isômero do CLA, na redução da gordura corporal e no combate à obesidade em humanos.

\subsection{Conclusões}

O sistema in vitro respondeu ao controle positivo (hormônio do crescimento) tanto para lipogênese (decréscimo), quanto para lipólise (aumento), como para a atividade da FAS (decréscimo), sugerindo estar adequado para os testes com CLA.

O tratamento com CLA trans-10, cis-12, na maior concentração $(200 \mu \mathrm{M})$, reduziu a atividade da FAS, enzima chave na regulação da síntese de lipídios, em relação ao ácido linoléico. Coerente com esta redução houve diminuições numéricas na abundância de RNAm da FAS e na taxa de síntese de lipídios. A mobilização lipídica não foi alterada sob efeito do CLA trans-10, cis-12. 


\section{CONCLUSÕES GERAIS}

Ensaios iniciais, consistentes com a literatura, demonstraram que a albumina sérica bovina altera as taxas de lipogênese e lipólise, não sendo um veículo adequado para apresentação de ácidos graxos bioativos ao tecido adiposo em cultura.

A utilização do PVA, em culturas de explante de tecido adiposo, não alterou o padrão de resposta celular (lipogênese e lipólise) ao hormônio do crescimento utilizado como controle positivo. Os resultados sugerem que esta é uma melhor opção de molécula carreadora de ácidos graxos em cultura.

Os efeitos do CLA trans-10, cis-12 no metabolismo de gordura foram tênues. Apenas o tratamento com a dosagem mais elevada (200 $\mu \mathrm{M}$ de CLA trans-10, cis-12) resultou em redução significativa da atividade da FAS, e reduções numéricas de $24 \%$ na abundância do seu RNAm e 6\% na lipogênese.

O CLA trans-10, cis-12 parece ter um efeito inibitório sobre o mecanismo de síntese de lipídios, mas não sobre a mobilização em culturas de tecido adiposo de suínos. 


\section{REFERÊNCIAS BIBLIOGRÁFICAS}

ABU-ELHEIGA, L.; MATZUK, M.M.; ABO-HASHEMA, K.A.H.; WAKIL,S.J. Continuous fatty acid oxidation and reduced fat storage in mice lacking acetyl-CoA carboxylase 2. Science, v.291, p.2613-2616, 2001.

BACK, D.W.; MITCHELL, J.G.; FISCH, J.E.; OEHC, R.S.;GOODRIDGE, A.G. The fatty acid synthase gene in avian liver. Two mRNAs are expressed and regulated in parallel by feeding, primarily at the level of transcription. The Journal of Biological Chemistry, v.261, p.4190-4197, 1986.

BAUMAN, D.E.; DAVIS, C.L. Regulation of lipid metabolism. In: McDONALD, I.W.; WARNER, A.C.I. (Ed). Digestion and metabolism in the ruminant. London: Butterworths, 1975. p.67-83.

BAUMAN, D.E.; VERNON, R.G. Effects of exogenous bovine somatotropin on lactation. Annual Review of Nutrition, v.13, p.437-461, 1993.

BAUMAN, D.E.; BROWN, R.E.; DAVIS, C.L. Pathways of fatty acid synthesis and reducing equivalent generation in mammary gland of rat, sow, and cow. Archives of Biochemistry and Biophysics, v.140, p.237-244, 1970.

BAUMAN, D.E.; BAUMGARD, L.H.; CORL, B.A.; GRIINARI, J.M. Biosynthesis of conjugated linoleic acid the ruminants. Proceedings of the American Society of Animal Science, v.48, p.1-15, 1999.

BAUMGARD, L.H.; SANGSTER, J.K.; BAUMAN, D.E. Milk fat synthesis in dairy cows is progressively reduced by increasing supplemental amounts of trans-10, cis-12 conjugated linoleic acid. Journal of Nutrition, v.131, p.1764-1769, 2001. 
BAUMGARD, L.H.; CORL, B.A.; DWYER, D.A.; SAEBO, A.; BAUMAN, D.E. Identification of the conjugated linoleic acid isomer that inhibits milk fat synthesis. American Journal of Physiology Regulatory, Integrative and Comparative Physiology, v.278, n.1, p.179-184, 2000.

BAUMGARD, L.H.; MATITASHVILI, E.; CORL, B.A.; DWYER, D.A.; BAUMAN, D.E. trans-10, cis-12 Conjugated linoleic acid decreases lipogenic rates and expression of genes involved in milk synthesis in dairy cows. Journal of Dairy Science, v.85, p.2155-2163, 2002.

BEE, G. Dietary conjugated linoleic acids clatter adipose tissue and milk lipids of pregnant and lactating sows. Journal of Nutrition, v.130, p.2292-2298, 2000.

BELURY, M.A. Inhibition of carcinogenesis by conjugated linoleic acid: potential mechanisms of action. Journal of Nutrition, v.132, p.2995-2998, 2002.

BOOTH, R.G.; KON, S.K., DANN, W.J., MOORE, T. XVII. A study of seasonal variation in butter fat. II A seasonal spectroscopic variation in the fatty acid fraction. Biochemical Journal, v.29, p.133-137, 1935.

BROWN, J.M.; McINTOSH, M.K. Conjugated linoleic acid in humans: regulation of adiposity and insulin sensitivity. Journal of Nutrition, v.133, p.3041-3046, 2003.

BROWN, J.M.; HALVORSEN, Y.D.; LEA-CURRIE, Y.R.; GEIGERMAN, C.; McINTOSH, M.K. Trans-10, cis-12 but not cis-9, trans-11, conjugated linoleic acid attenuates lipogenesis in primary cultures of stromal vascular cells from human adipose tissue. Journal of Nutrition, v.131, p.2316-2321, 2001.

BHUIYAN, M.M.U.; CHO, J-k.; JANG, G.; PARK, E-s.; KANG, S-k.; LEE, B-c.; HWANG, W-s. Effect of protein supplementation in potassium simplex optimization medium on preimplantation development of bovine non-transgenic and transgenic cloned embryos. Theriogenology, v.62, p.1403-1416, 2004.

CHIN, S.F.; LIU, W.; STORKSON, J.M.; HA, Y.L.; PARIZA, M.W. Dietary sources of conjugated dienoic isomers of linoleic acid a newly recognized class of anticarcinogens. Journal of Food Composition and Analysis, v.5, p.185-197, 1992. 
CHOI, Y.; KIM, Y-C; HAN, Y-B.; PARK, Y.; PARIZA, M.W.; NTAMBI, J.M. The trans-10, cis-12 isomer of conjugated linoleic acid downregulates stearoyl-CoA desaturase 1 gene expression in 3T3-L1 adipocytes. Journal of Nutrition, v.130, p.1920-1924, 2000.

CHOUINARD, P.Y.; CORNEAU, L.; BARBANO, D.M.; METZGER, L.E.; BAUMAN, D.E. Conjugated linoleic acids alter milk fatty acid composition and inhibit milk fat secretion in dairy cows. Journal of Nutrition, v.129, p.1579-1584, 1999.

CLARKE, S.D. Regulation of fatty acid synthase gene expression: an approach for reducing fat accumulation. Journal of Animal Science, v.71, p.1957-1965, 1993.

CLARKE, S.D.; JUMP, D.B. Regulation of gene transcription by polyunsaturated fatty acids. Progress on Lipids Research, v.32, p.139-149, 1993.

CORINO, C.; MAGNI, S.; PASTORELLI, G.; ROSSI, R.; MOUROT, J. Effect of conjugated linoleic acid on meat quality, lipid metabolism, and sensory characteristics of dry-cured hams from heavy pigs. Journal of Animal Science, v.81, p.2219-2229, 2003.

CORINO, C.; MOUROT, J.; AGNI, S.; PASTORELLI, G.; ROSSI, R.. Effect of dietary conjugated linoleic acid on growth, meat quality, lipogêneses, plasma leptin and physiological variables of lipid metabolism in rabbits. Journal of Animal Science, v.80, p.1020-1028, 2002.

CORL, B.A.; BAUMGARD, L.H.; DWYER, D.A.;GRIINARI, J.M.; PHILLIPS, B.S.; BAUMAN, D.E. The role of $\Delta^{9}$ desaturase in the production of cis-9, trans-11 CLA. Journal of Nutritional Biochemistry, v.12, p.622-630, 2001.

DANN, W.J.; MOORE, T. The absorption spectra of the mixed fatty acids from cod liver oil. Biochemical Journal, v.27, p.1166-1169, 1933.

DANN, W.J.; MOORE, T.; BOOTH, R.G.; GOLDING, J.; KON, S.K. A new spectroscopic phenomenon in fatty acid metabolism. The conversion of " pro-absorptive to absorptive acids in the cow. Biochemical Journal, v.29, p.138-146, 1935.

DEMAREE, S.R.; GILBERT, C.D.; MERSMANN, H.J.; SMITH, S.B. Conjugated linoleic acid differentially modifies fatty acid composition in subcellular fractions of 
muscle and adipose tissue but not adiposity of postweanling pigs. Journal of Nutrition, v.132, p.3272-3279, 2002.

DICE, J.F.; GOLDBERG, A.L. Statistical analysis of the relationship between degradative rates and molecular weights of proteins. Archives of Biochemistry and Biophysics, v.170, n.1, p.213-219. 1975.

DING, S-T.; McNEEL, R.L.; MERSMANN, H.J. Conjugated linoleic acid increases the differentiation of porcine adipocytes in vitro. Nutrition Research, v.20, p.1569$1580,2000$.

DUGAN, M.E.R.; AALHUS, J.L.; SCHAEFER, A.L.; KRAMER, J.K.G. The effect of conjugate linoleic acid on fat to lean repartitioning and feed conversion in pigs. Canadian Journal of Animal Science, v.77, p.723-725, 1997.

DUGAN, M.E.R.; AALHUS, J.L.; JEREMIAH, L.E.; KRAMER, J.K.G.; SCHAEFER, A.L. The effects of feeding conjugate linoleic acid on subsequent pork quality. Canadian Journal of Animal Science, v.79, p.45-51, 1999.

DUNSHEA, F.R.; HARRIS, D.M.; BAUMAN, D.E.; BOYD, R.D.; BELL, A.W. Effect of porcine somatotropin on in vivo glucose kinetics and lipogenesis in growing pigs. Journal of Animal Science, v.70, p.141-151, 1992.

DUNSHEA， F.R.; OSTROWSKA， E.; MURALITHARAN, M.; CROSS, R.; BAUMAN, D.E.; PARIZA, M.W.; SKARIE, C. Dietary conjugated linoleic acid decreases bak fat in growing gilts. Journal of Animal Science, v.76, Suppl.1, p.131, 1998.

EGGERT, J.M.; BELURY, M.A.; KEMPA-STECZKO, A.; MILLS, S.E.; SCHINCKEL,A.P. Effects of conjugated linoleic acid on the belly firmness and fatty acid composition of genetically lean pigs. Journal of Animal Science, v.79, p.2866-2872, 2001.

ETHERTON, T.D.; BAUMAN, D.E. Biology of somatotropin in growth and lactation of domestic animals. Physiological Reviews, v.78, p.745-761, 1998.

ETHERTON, T.D.; DONKIN, S.S.; BAUMAN, D.E. Mechanisms by which porcine somatotropin (pST) decreases adipose tissue growth in growing pigs. In: SMITH, 
S.B.; SMITH, D.R. The biology of fat in meat animals. Champaign: IL.: American Society of Animal Science, 1995. p.53-69.

EVANS, M.; LIN, X.; ODLE, J.; McINTOSH, M. Trans-10, cis-12 conjugated linoleic acid increases fatty acid oxidation in 3T3L1 preadipocytes. Journal of Nutrition, v.132, p.450-455, 2002.

EVANS, M.; GEIGERMAN, J.; COOK, J.; CURTIS, L.; KUEBLER, B.; McINTOSH, M. Conjugated linoleic acid suppresses triglyceride accumulation and induces apoptosis in 3T3-L1 preadipocytes. Lipids, v.35, p.899-910, 2000.

FOLCH, J.; LEES, M.; SLOANE STANLEY, G.H. A simple method for the isolation and purification of total lipids from animal tissues. Journal of Biological Chemistry, v.226, p.497-509, 1957.

GATLIN, L.A.; SEE, M.T.; LARICK, D.K.; LIN, X.; ODLE, J. CONJUGATED linoleic acid in combination with supplemental dietary fat alters pork fat quality. Journal of Nutrition, v.132, p.3105-3112, 2002.

GIESY, J.G.; HANSON, T.W.; ROBINSON, M.; HAFLIGER, S.; VISWANADHA, M.A.; MCGUIRE, M.A.; SKARIE, C.H.; VINCI, A. Effects of calcium salts of conjugated linoleic acid on milk yield, fat and CLA content of milk fat in Holstein cows early in lactation. Journal of Animal Science,v.77, Suppl.1, p.74, 1999.

GIULIETTI, A.; OVERBERGH, L.; VALCKX, D.; DECALLONNE, B.; BOUILLON, R.; MATHIEU, C. An overview of Real-Time Quantitative PCR: Applications to quantify cytokine gene experssion. Methods, v.25, p.386-401, 2001.

GLOCK, G.E.; McLEAN, P. Further studies on the properties and assay of glucose 6phophaste dehydrogenase and 6-phosphogluconate dehydrogenase of rat liver. Biochemical Journal, v.55, p.400-408, 1953.

GORNALL, A.G.; BRADAWILL, C.T.; DAVID, M.M. Determination of serum protein by means of biuret reagent. Journal of Biological Chemistry, v. 177, p.751-766, 1949.

GRIINARI, J.M.; DWYER, D.A.; MCGUIRE, M.A.; BAUMAN, D.E.; PALMQUIST, D.L.; NURMELA, K.V.V. Trans-octadecenoic acids and milk fat depression in lactating cows. Journal of Dairy Science, v.81,p.1251-1261, 1998. 
HA, Y.L.; GRIMM, N.K.; PARIZA, M.W. Anticarcinogens from fried ground beef: Heat-altered derivatives of linoleic acid. Carcinogenesis, v.8, p.1881-1887, 1987.

HAYASHI, A.A. Efeito da suplementação com ácido linoléico conjugado (CLA) na composição do leite, no perfil de ácidos graxos e na atividade de enzimas lipogênicas em ratas lactantes. Piracicaba, 2003. 68p. Dissertação (Mestrado) - Escola Superior de Agricultura "Luiz de Queiroz", Universidade de São Paulo.

HOUSEKNECHT, K.L.; HEUVEL, J.P.V.; CAMARENA-MOYA, S.Y.; PORTOCARRERO, C.P.; PECK, L.W., NICKEL, K.P.; BELURY, M.A. Dietary conjugated linoleic acid normalizes impaired glucose tolerance in the Zucker diabetic fatty fa/fa rat. Biochemical and Biophysical Research Communications, v.244, p.678-682, 1998.

INGLE， D.L.; BAUMAN， D.E.; MELLENBERGER， R.W.; JOHNSON， D.E. Lipogenesis in the ruminant: effect of fasting and refeeding on fatty acid synthesis and enzymatic activity of sheep adipose tissue. Journal of Nutrition, v.103, p.14791488, 1973.

IP, C.; BANNI, S.; ANGIONI, E.; CARTA,G.; McGINLEY, J.; THOMPSON, H.J.; BARBANO, D.; BAUMAN, D.E. Conjugated linoleic acid-enriched butter fat alters mammary gland morphogenesis and reduces cancer risk in rats. Journal of Nutrition, v.129, p.2135-2142, 1999.

JOSÉ, A.A.F.B.V. Efeito do hormônio do crescimento na expressão gênica da sintetase de ácidos graxos em animais em crescimento. Piracicaba, 2000. 65p. Dissertação (Mestrado) - Escola Superior de Agricultura "Luiz de Queiroz”, Universidade de São Paulo.

KELLY, M.L.; BERRY, J.R.; DWYR, D.A.; GRIINARI, J.M.; CHOUNARD, P.Y.; VAN AMBURGH, M.E.; BAUMAN, D.E. Dietary fatty acid sources affect conjugated linoleic acid concentrations in milk from lactating dairy cows. Journal of Nutrition, v.128, p.881-885, 1998.

KEPLER, C.R.; HIRONS, K.P.; McNELL, J.J.; TOVE, S.B. Intermediates and products of the biohydrogenation of linoleic acid by Butyribrio fibrisolvens. Journal of Biological Chemistry, v.241, p.1350-1354, 1966. 
LANNA, D.P.D. Cellular Mechanisms of Somatotropin Control of Lipogenesis and Lipolysis in Adipose Tissue of Lactating and Growing Animals. Ithaca,1993. 205p. Tese $(\mathrm{PhD})$ - Cornell University.

LANNA, D.P.D.; BAUMAN, D.E. Effect of somatotropin, insulin, and glucocorticoid on lipolysis in chronic cultures of adipose tissue from lactating cows. Journal of Dairy Science, v.82, n.1, p.60-68, 1999.

LANNA, D.P.D.; DWYER, D.A.; BAUMAN, D.E. Somatotropin and the control of lipogenesis by insulin and adenosine in pig adipose tissue. Journal of Animal Science, v.72, p.161, 1994.

LANNA, D.P.D.; HOUSEKNECHT, K.L.; HARRIS, D.M.; BAUMAN, D.E. Effects of somatotropin treatment on lipogenesis, lipolysis and related cellular mechanisms in adipose tissue of lactating cows. Journal of Dairy Science, v.78, n.8, p.1703-1712, 1995.

LEE, K.N.; PARIZA, M.W.; NTAMBI, J.M. Conjugated linoleic acid decreases hepatic stearoyl-CoA desaturase mRNA expression. Biochemical and Biophysical Research Communications, v.248, p.817-821, 1998.

LIN, X.; LOOR, J.J.; HERBEIN, J.H. Trans10,cis12-18:2 Is a more potent inhibitor of de novo fatty acid synthesis and desaturation than cis9,trans11-18:2 in the mammary gland of lactating mice. Journal of Nutrition, v.134, p.1362-1368, 2004.

LITTEL, R.C.; MILLIKEN, G.A.; STROUP, W.W.; WOLFINGER, R.D. SAS system for mixed models. Cary: SAS Institute, 1996. 633p.

MAHONEY, E.M.; HAMILL, A.L.; SCOTT, W.A.; COHN, Z.A. Response of endocytosis to altered fatty acid composition of macrophage phospholipids. Proceedings of the National Academy of Science of the USA, v.74, p.4895-4899, 1977.

MALONEY, F.; YEOW, T-P.; MULLEN, A.; NOLAN, J.J.; ROCHE, H.M. Conjugated linoleic acid supplementation, insulin, sensitivity, and lipoprotein metabolism in patients with type 2 diabetes mellitus. American Journal of Clinical Nutrition, v.80, p.887-895, 2004. 
MATITASHVILI, E.; BAUMGARD, L.H.; BAUMAN, D.E. The effect of trans-10, cis-12 conjugated linoleic acid (CLA) infusion on milk fat synthesis and expression of lipogenic enzymes in the mammary gland of lactating cows. Journal of Animal Science, v.79, Suppl.1., p.310, 2001.

MEADUS, W.J.; MACINNIS, R.; DUGAN, M.E.R. Prolonged dietary treatment with conjugated linoleic acid stimulates porcine muscle peroxisome proliferator activated receptor $\gamma$ and glutamine -fructose aminotransferase gene expression in vivo. Journal of Molecular Endocrinology, v. 28, p. 79-86, 2002.

MEDEIROS, S.R.; OLIVEIRA, D.E.; AROEIRA, L.J.M.; MCGUIRE, M.; BAUMAN, D.E.; LANNA, D.P.D. The effect of long-term supplementation of conjugated linoleic acid (CLA) to dairy cows grazing tropical pasture. Journal of Animal Science, v.78, Suppl.1, p.169, 2000.

MERSMANN, H.J. Mechanisms for conjugated linoleic acid-mediated reduction in fat deposition. Journal of Animal Science, v.80, Suppl.2, p.E126-E134, 2001.

MOYA-CAMARENA, S.Y.; BELURY, M.A. Species differences in the metabolism and regulation of gene expression by conjugate linoleic acid. Nutrition Reviews, v.57, p.336-340, 1999.

NOWSHARI, M.A.; BREN, G. The protective action of polyvinyl alcohol during rapidfreezing of mouse embryos. Theriogenology, v.53, p.1157-1166, 2000.

O'QUINN, P.R.; NELSSEN, J.L.; GOODBAND, R.D.; UNRUH, J.A.; WOODWORTH, J.C.; SMITH, J.S.; TOKACH, M.D. Effects of modified tall oil versus a commercial source of conjugated linoleic acid and increasing levels of modified tall oil on growth performance and carcass characteristics of growingfinishing pigs. Journal of Animal Science, v.78, p.2359-2368, 2000.

ORSI, N.M.; LEESE, H.J. Amino acid metabolism of preimplantation bovine embryos cultured with bovine serum albumin or polyvinyl alcohol. Theriogenology, v.61, p.561-572, 2004.

OSTROWSKA, E.; MURALITHARAN, M.; CROSS, R.F.; BAUMAN, D.E.; DUNSHEA, F.R. Dietary conjugated linoleic acids increase lean tissue and decrease fat deposition in growing pigs. Journal of Nutrition, v.129, p.2037-2042, 1999. 
OSTROWSKA, E.; CROSS, R.F.; MURALITHARAN, M.; BAUMAN, D.E.; DUNSHEA, F.R. Dietary conjugated linoleic acid differentially alters fatty acid composition and increases conjugated linoleic acid content in porcine adipose tissue. British Journal of Nutrition, v.90, p.915-928, 2003a.

OSTROWSKA, E.; SUSTER, D.; MURALITHARAN, M.; CROSS, R.F.; LEURY, B.J.; BAUMAN, D.E.; DUNSHEA, F.R. Conjugated linoleic acid decreases fat accretion in pigs: evaluation by dual-energy X-ray absorptiometry. British Journal of Nutrition, v.89, p.219-229, 2003 b.

PARIZA, M.W.; PARK, Y.; COOK, M.E. Mechanisms of action of conjugated linoleic acid: evidence and speculation. Proceedings of Society for Experimental Biology and Medicine, v.223, p.9-13, 2000.

PARIZA, M.W.; PARK, Y.; COOK, M.E. The biologically active isomers of conjugated linoleic acid. Proceedings in Lipid Research, v.40, p.283-298, 2001.

PARIZA, M.W.; ASHOOR, S.H.; CHU, F.S.; LUND, D.B. Effects of temperature and time on mutagem formation in pan fried hamburger. Cancer Letters, v.7, p.63-69, 1979.

PARIZA, M.W.; LORETS, L.J.; STORKSON, J.M.; HOLLAND, N.C. Mutagens and modulator of mutagenesis in fried ground beef. Cancer Research, v.43, Suppl. 2444s-2446s, 1983.

PARK, Y.; PARIZA, M.W. The effects of dietary conjugated nonadecadienoic acid on body composition in mice. Biochemical and Biophysical Acta, v.1534, p.27-33, 2001.

PARK, Y.; STORKSON, J.M.; ALBRIGHT, K.J.; LIU, W.; PARIZA, M.W. Evidence that the trans-10, cis-12 isomer of conjugated linoleic acid induces body composition changes in mice. Lipids, v.34, p.235-241, 1999.

PARK, Y.; ALBRIGHT, K.J.; LIU, W.; STORKSON, J.M.; COOK, M.E.; PARIZA, M.W. Effect of conjugated linoleic acid on body composition in mice. Lipids, v. 32, p. 853-858, 1997.

PARK, Y.; STORKSON, J.M.; NTAMBI, J.M.; COOK, M.E.; SIH, C.J.; PARIZA, M.W. Inhibition of hepatic stearoyl-CoA desaturase activity by trans-10, cis-12 conjugated 
linoleic acid and its derivatives. Biochimica et Biophysica Acta, v.1486, p.285-292, 2000.

PARODI, P.W. Conjugated octacecadienoic acids of milk fat. Journal of Dairy Science, v.60, p.1550-1553, 1977.

PARODI, P.W. Cow's milk fat components as potential anticarcinogenic agents. Journal of Nutrition, v.127, p.1055-1060, 1997.

PERFIELD, J.W.; BERNAL-SANTOS, G.; OVERTON, T.R.; BAUMAN, D.E. Effects of dietary supplementation of rumen-protected conjugated linoleic acid in dairy cows during established lactation. Journal of Dairy Science, v.85, p.1-9, 2002.

PETERSON, D.G.; MATITASHVILI, E.A.; BAUMAN, D.E. Diet-induced milk fat depression in dairy cows results in increased trans-10, cis-12 CLA in milk fat and coordinate suppression of mRNA abundance for mammary enzymes involved in milk fat synthesis. Journal of Nutrition, v.133, p.3098-3102, 2003.

PFAFFL, M. W. A new mathematical model for relative quantification in real-time RTPCR. Nucleic Acids Research, v.29, p.2002-2007, 2001.

PIPEROVA, L.S.; MOALLEM, U.; TETER, B.B.; SAMUGNA, J.; YURAWECZ, M.P.; MOREHOUSE, K.M.; LUCHINI, D.; ERDMAN, R.A. Changes in milk fat in response to dietary supplementation with calcium salts of trans-18:1 or conjugated linoleic fatty acids in lactating dairy cows. Journal of Dairy Science, v.87, p.3836-3844, 2004.

PIPEROVA L.S.; TETER, B.B.; BRUCKENTAL, I.; SAMPUGNA, J.; MILLS, S.E.; YURAWECZ, M.P.; FRITSCHE, J.; KU, K.; ERDMAN, R.A. Mammary lipogenic enzyme activity, trans fatty acids and conjugated linoleic acids are altered in lactating dairy cows fed a milk fat-depressing diet. Journal of Nutrition, v.130, p.2568-2574, 2000.

REISER, R. Hydrogenation of polyunsaturated fatty acids by the ruminant. Federation Proceedings, v.10, 236p, 1951.

SAKONO, M.; MIYANAGA, F.; KAWAHARA, S.; YAMAUCHI, K.; FUKUDA, N.; WATANABE, K.; IWATA, T.; SUGANO, M. Dietary conjugated linoleic acid reciprocally modifies ketogenesis and lipid secretion by the rat liver. Lipids, v.34, p.997-1000, 1999. 
SAS INSTITUTE. SAS/SAT: user's guide. Cary, 1999.

SATORY, D.L.; SMITH, S.B. Conjugated linoleic acid inhibits proliferation but stimulates lipid filling of murine 3T3-L1 preadipocytes. Journal of Nutrition, v.129, p.92-97, 1999.

SCOTT, W.E.; HERB, S.F.; MAGIDMAN, P.; RIEMENSCHNEIDER, R.W. Unsaturated fatty acids of butterfat. Journal of Agricultural and Food Chemistry, v.7, p.125, 1959.

SEBEDIO, J.L.; GNAEDIG, S.; CHARDIGNY,J.M. Recent advances in conjugated linoleic acid research. Current Opinion Clinical Nutrition Metabolic Care, v.2, n.6, p.499-506, 1999.

SINNETT-SMITH, P.A.; VERNON, R.G.; MAYER, R.J. Fatty acid synthesis and the activities of fatty acid synthesizing in rat adipose tissue during pregnancy and lactaion. Biochemical Society Transactions, v.7, n.2, p.388-389, 1979.

SMITH, L.M.; FREEMAN, N.K.; JACK, E.L. The unsaturated fatty acids of milk fat. III. Geometrical isomerism. Journal of Dairy Science, v. 37, p.399, 1954.

SMITH, S.B.; HIVELY, T.S.; CORTESE, G.M.; HAN, J.J.; CHUNG, K.L.; CASTEÑADA, P.; GILBERT, C.D.; ADAMS, V.L.; MERSMANN, H.J. Conjugated linoleic acid depresses the $\Delta^{9}$ desaturase index and stearoyl coenzyme A desaturase enzyme activity in porcine subcutaneous adipose tissue. Journal of Animal Science, v.80, p.2110-2115, 2002.

SPECTOR, A.A. Structure and lipid binding properties of serum albumin. Methods in Enzymology, v.128, p.320-339, 1986.

TAKAHASHI, Y.; KUSHIRO, M.; SHINOHARA, K.; IDE, T. Dietary conjugated linoleic acid reduces body fat mass and affects gene expression of proteins regulating energy metabolism in mice. Comparative Biochemistry and Physiology, v. 133, p.395-404, 2002.

TAKAHASHI, Y.; KUSHIRO, M.; SHINOHARA, K.; IDE, T. Activity and mRNA levels of enzymes involved in hepatic fatty acid synthesis and oxidation in mice fed conjugated linoleic acid. Biochemical and Biophysical Acta, v.1631, p.265-273, 2003. 
THIEL-COOPER, R.L.; PARRISH, F.C.; SPARKS, J.C.; WIEGAND, B.R.; EWAN, R.C. Conjugated linoleic acid changes swine performance and carcass composition. Journal of Animal Science, v.79, p.1821-1828, 2001.

TRICON, S.; BURDGE, G.C.; KEW, S.; BANERJEE, T.; RUSSEL, J.J.; JONES, E.L.; GRIMBLE, R.F.; WILLIAMS, C.M.; YAQOOB, P.; CALDER, P.C. Opposing effects of cis-9, trans-11 and trans-10, cis-12 conjugated linoleic acid on blood lipids in healthy humans. American Journal of Clinical Nutrition, v.80, p.614-620, 2004.

TRONSTAD, K.J.; BERGE, K.; FLINDT, E.N.; KRISTIANSEN, K.; BERGE, R.K. Optimization of methods and treatments conditions for sutdying effects of fatty acids on cell growth. Lipids, v.36, n.3, p.305-313, 2001

WAHLE, K.W.J.; HEYS, S.D. Cell signal mechanisms, conjugated linoleic acids (CLAs) and anti-tumorigenesis. Prostaglandins, Leukotrienes and Essencial Fatty Acids, v.67, p.183-186, 2002.

WALTON, P.E.; ETHERTON, T.D. Stimulation of lipogenesis by insulin in swine adipose tissue antagonism by porcine growth hormone. Journal of Animal Science, v.62, p.1584-1595, 1986.

WIEGAND, B.R.; SPARKS, J.C.; PARRISH Jr., F.C.; ZIMMERMAN, D.R. Duration of feeding conjugated linoleic acid influences growth performance, carcass traits, and meat quality of finishing barrows. Journal of Animal Science, v.80, p.637-643, 2002 .

XU, X.; STORKSON, J.; KIM, S.; SUGIMOTO, K.; PARK, Y.; PARIZA, M.W. Shortterm intake of conjugated linoleic acid inhibits lipoprotein lipase and glucose metabolism but does not enhance lipolysis in mouse adipose tissue. Journal of Nutrition, v.133, p.663-667, 2003. 